\title{
Anthropogenic Organic Compounds in Source and Finished Water from Community Water System Wells in Western and Central Connecticut, 2002-2004
}

By Thomas J. Trombley, Craig J. Brown, and Gregory C. Delzer

National Water-Quality Assessment Program

Source Water-Quality Assessments

Scientific Investigations Report 2007-5171 


\section{U.S. Department of the Interior DIRK KEMPTHORNE, Secretary}

\section{U.S. Geological Survey \\ Mark D. Myers, Director}

U.S. Geological Survey, Reston, Virginia: 2007

For product and ordering information:

World Wide Web: http://www.usgs.gov/pubprod

Telephone: 1-888-ASK-USGS

For more information on the USGS — the Federal source for science about the Earth, its natural and living resources, natural hazards, and the environment:

World Wide Web: http://www.usgs.gov

Telephone: 1-888-ASK-USGS

Any use of trade, product, or firm names is for descriptive purposes only and does not imply endorsement by the U.S. Government.

Although this report is in the public domain, permission must be secured from the individual copyright owners to reproduce any copyrighted materials contained within this report.

Suggested citation:

Trombley, T.J., Brown, C.J., and Delzer, G.C., 2007, Anthropogenic organic compounds in source and finished water from community water system wells in western and central Connecticut, 2002-2004: U.S. Geological Survey Scientific Investigations Report 2007-5171, 38 p. 


\section{Foreword}

The U.S. Geological Survey (USGS) is committed to providing the Nation with accurate and timely scientific information that helps enhance and protect the overall quality of life and that facilitates effective management of water, biological, energy, and mineral resources ( $h$ ttp:// www.usgs.gov/. Information on the quality of the Nation's water resources is critical to assuring the long-term availability of water that is safe for drinking and recreation and suitable for industry, irrigation, and habitat for fish and wildlife. Population growth and increasing demands for multiple water uses make water availability, now measured in terms of quantity and quality, even more essential to the long-term sustainability of our communities and ecosystems.

The USGS implemented the National Water-Quality Assessment (NAWQA) Program in 1991 to support national, regional, and local information needs and decisions related to water-quality management and policy (http://water.usgs.gov/nawqa). Shaped by and coordinated with ongoing efforts of other Federal, State, and local agencies, the NAWQA Program is designed to answer: What is the condition of our Nation's streams and ground water? How are the conditions changing over time? How do natural features and human activities affect the quality of streams and ground water, and where are those effects most pronounced? By combining information on water chemistry, physical characteristics, stream habitat, and aquatic life, the NAWQA Program aims to provide science-based insights for current and emerging water issues and priorities.

From 1991-2001, the NAWQA Program completed interdisciplinary assessments in 51 of the Nation's major river basins and aquifer systems, referred to as Study Units (http://water.usgs. gov/ nawqa/studyu.html. Baseline conditions were established for comparison to future assessments, and long-term monitoring was initiated in many of the basins. During the next decade, 42 of the 51 Study Units will be reassessed so that 10 years of comparable monitoring data will be available to determine trends at many of the Nation's streams and aquifers. The next 10 years of study also will fill in critical gaps in characterizing water-quality conditions, enhance understanding of factors that affect water quality, and establish links between sources of contaminants, the transport of those contaminants through the hydrologic system, and the potential effects of contaminants on humans and aquatic ecosystems.

The USGS aims to disseminate credible, timely, and relevant science information to inform practical and effective water-resource management and strategies that protect and restore water quality. We hope this NAWQA publication will provide you with insights and information to meet your needs, and will foster increased citizen awareness and involvement in the protection and restoration of our Nation's waters.

The USGS recognizes that a national assessment by a single program cannot address all waterresource issues of interest. External coordination at all levels is critical for a fully integrated understanding of watersheds and for cost-effective management, regulation, and conservation of our Nation's water resources. The NAWQA Program, therefore, depends on advice and information from other agencies - Federal, State, interstate, Tribal, and local—as well as nongovernmental organizations, industry, academia, and other stakeholder groups. Your assistance and suggestions are greatly appreciated.

Robert M. Hirsch 



\section{Contents}

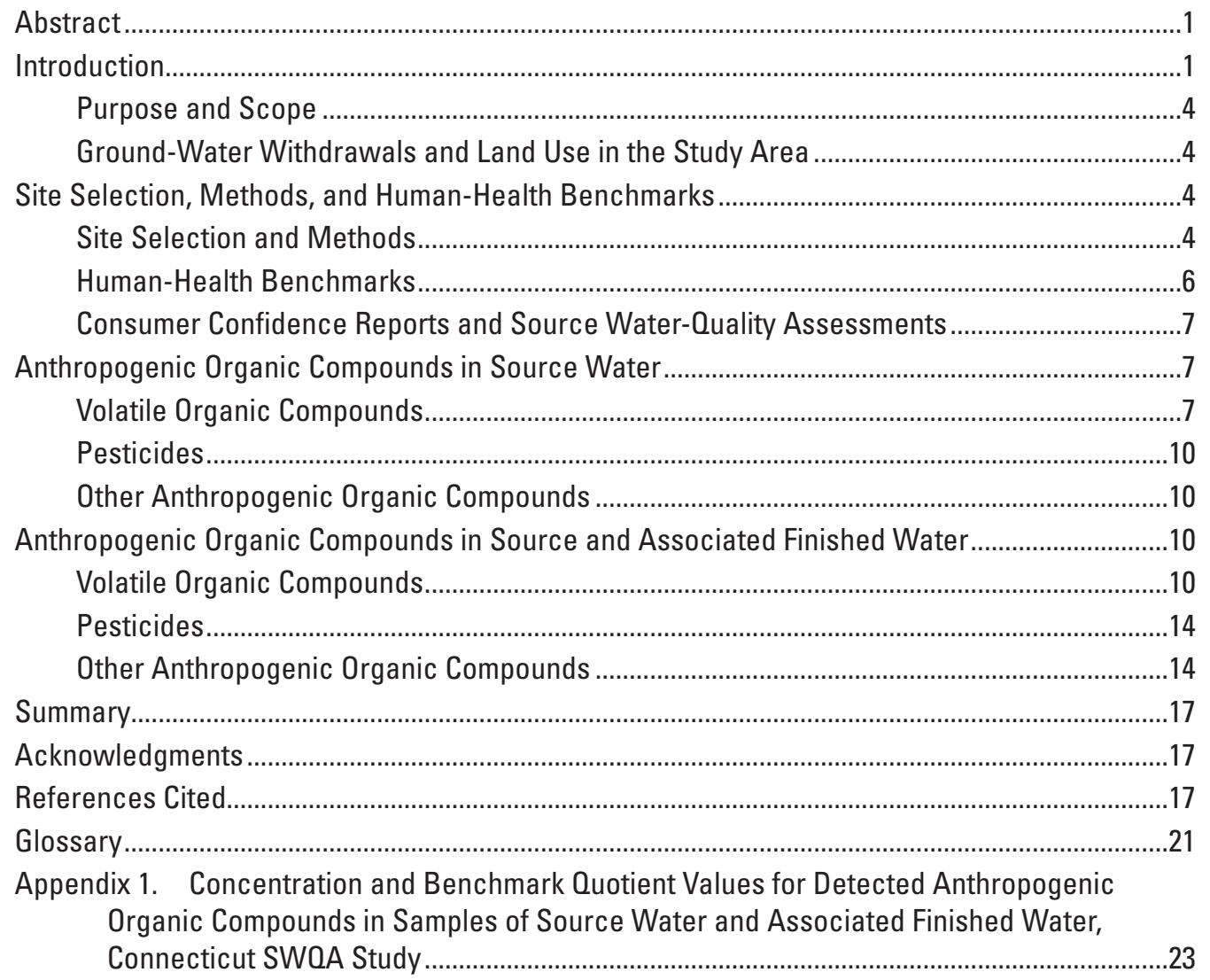

\section{Figures}

1-3. Maps showing-

1. Location of National Water-Quality Assessment (NAWQA) study units and Ground-Water Source Water-Quality Assessment (SWQA) study areas ..................2

2. Glacial stratified aquifer in western and central Connecticut and location of community water system wells sampled in Phase I (source water) and Phase II (source and finished water) of the Connecticut source waterquality assessment

3. Land use in western and central Connecticut and location of community water system wells sampled in Phase I (source water) and Phase II (source and finished water) of the Connecticut source water-quality assessment 
4-7. Graphs showing -

4. Concentration, number of detections, and benchmark quotient values for $(A)$ volatile organic compounds, $(B)$ pesticides, and $(C)$ other anthropogenic organic compounds detected in 15 community water system wells sampled in Phase I (source water) of the Connecticut source water-quality assessment ........9

5. (A) Concentrations and number of detections and $(B)$ benchmark quotient values for volatile organic compounds detected in 10 community water system wells sampled in Phase II (source and finished water) of the Connecticut source water-quality assessment.

6. (A) Concentrations and number of detections and $(B)$ benchmark quotient values for pesticides detected in 10 community water system wells sampled in Phase II (source and finished water) of the Connecticut source water-quality assessment.

7. (A) Concentrations and number of detections and $(B)$ benchmark quotient values for other anthropogenic organic compounds detected in 10 community water system wells sampled in Phase II (source and finished water) of the Connecticut source water-quality assessment.

\section{Tables}

1. Detection frequency, maximum concentration, and maximum benchmark quotient value for anthropogenic organic compounds detected in 15 community water system wells sampled in Phase I (source water) of the Connecticut source waterquality assessment.

2. Detection frequency, maximum concentration, and maximum benchmark quotient value for anthropogenic organic compounds detected in 10 community water system wells sampled in Phase II (source and finished water) of the Connecticut source water-quality assessment 


\section{Conversion Factors, Abbreviations, Datums, and Acronyms}

Distances in kilometers may be converted to miles by multiplying by 0.6214 .

Concentrations of chemical constituents are given in micrograms per liter $(\mu \mathrm{g} / \mathrm{L})$.

Vertical coordinate information is referenced to the North American Vertical Datum of 1988 (NAVD 88).

Horizontal coordinate information is referenced to the North American Datum of 1983 (NAD 83).

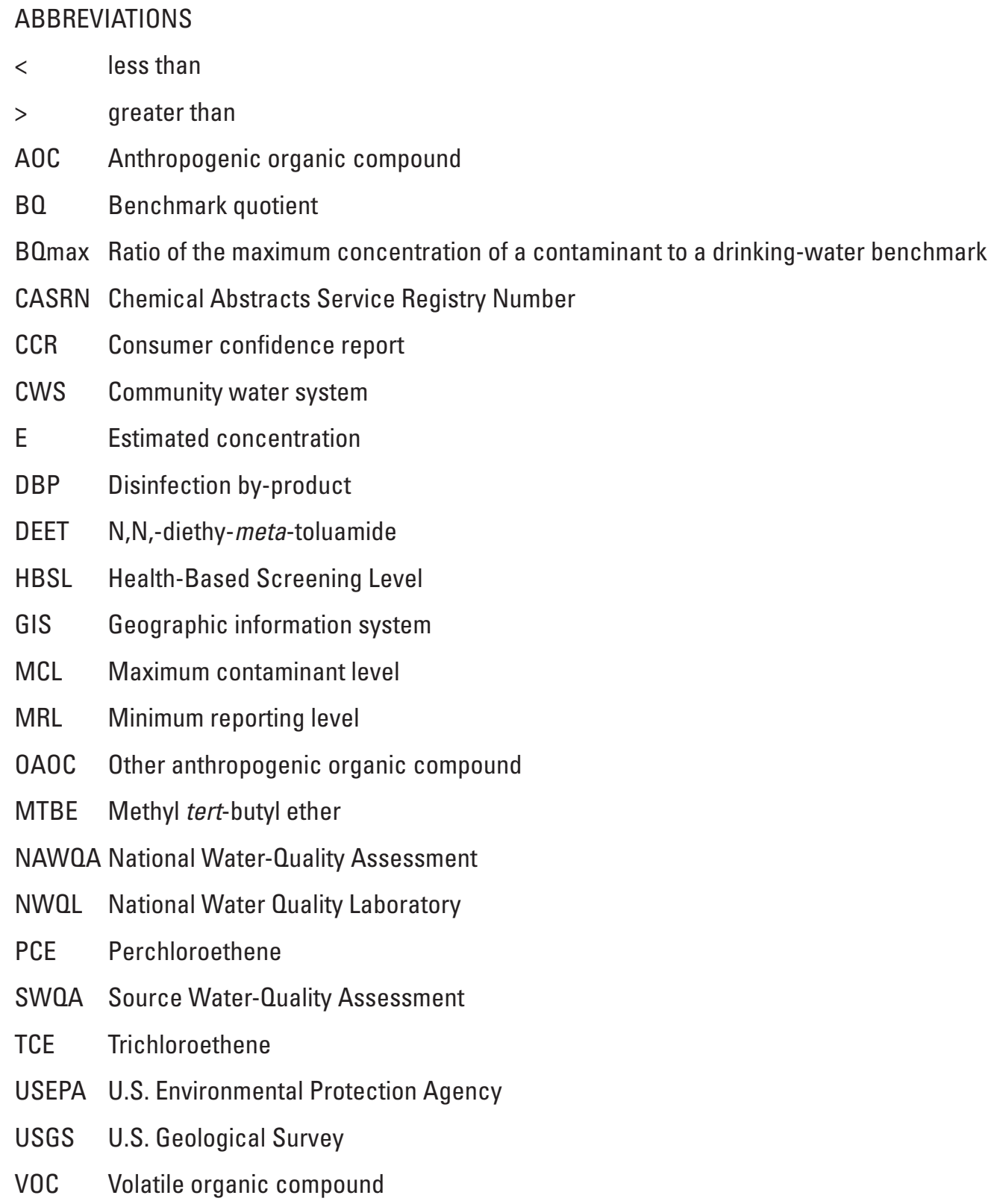





\title{
Anthropogenic Organic Compounds in Source and Finished Water from Community Water System Wells in Western and Central Connecticut, 2002-2004
}

\author{
By Thomas J. Trombley, Craig J. Brown, and Gregory C. Delzer
}

\section{Abstract}

A water-quality assessment by the U.S. Geological Survey (USGS) determined the occurrence of anthropogenic (manmade) organic compounds (AOCs) in water from 15 community water system (CWS) wells and associated finished drinking water. The study, which focused on water from the unconfined glacial stratified aquifer in western and central Connecticut, was conducted as part of the USGS National Water-Quality Assessment Program (NAWQA) Source WaterQuality Assessment (SWQA) project and included analysis of water samples for 88 volatile organic compounds (VOCs), 120 pesticides, and 50 other anthropogenic organic compounds (OAOCs).

During Phase I of the study, 25 AOCs were detected (12 VOCs, 10 pesticides, and 3 OAOCs) in source-water samples collected from 15 CWS wells sampled once from October 2002 to May 2003. Although concentrations generally were low (less than 1 microgram per liter), four compounds were detected at higher concentrations in ground water from four wells. The most frequently occurring AOCs were detected in more than half of the samples and included chloroform (87 percent), methyl tert-butyl ether (MTBE, 80 percent), 1,1,1-trichloroethane (67 percent), atrazine (60 percent), deethylatrazine (60 percent), perchloroethene (PCE, 53 percent), and simazine (53 percent). Trichloroethene (TCE) was detected in 47 percent of samples. Samples generally contained a mixture of compounds ranging from 2 to 19 detected compounds, with an average of 8 detected compounds per sample.

During Phase II of the study, 42 AOCs were detected in source-water samples collected from 10 resampled CWS wells or their associated finished water. Trihalomethanes accounted for most of the VOCs detections with all concentrations less than 1 microgram per liter. Chloroform, the most frequently detected VOC, was found in all source-water and all finished-water samples. As with the Phase I samples, other frequently detected VOCs included MTBE, and the solvents 1,1,1-trichloroethane, PCE, and TCE. Triazine herbicides and their degradation products accounted for most of the detected pesticides.

\section{Introduction}

In 1991, the U.S. Geological Survey (USGS) began the National Water-Quality Assessment (NAWQA) Program to (1) provide a nationally consistent description of current water-quality conditions for more than 50 of the largest and most important river basins and aquifers across the Nation; (2) define long-term trends in water quality; and (3) identify, describe, and explain, as much as possible, the major factors that affect observed water-quality conditions and trends. This information, which is obtained on a continuing basis, is made available to water managers, policy makers, and the public to help address and prioritize the multitude of issues related to managing and protecting our water resources.

Beginning in 2001, the NAWQA Program began its second decade of intensive assessment activities by returning to 42 of the original river basins and aquifers studied during the first decade to build upon the initial assessments of water-quality conditions and establish links between sources, transport, and the potential effects of contaminants on humans and aquatic ecosystems. This is accomplished through a variety of new, focused study components within the NAWQA Program. One such new assessment activity focuses on characterizing the quality of rivers and aquifers used as a source of supply to community water systems $(\mathbf{C W S s})^{1}$ in many of the NAWQA study basins (fig. 1). These activities are called Source Water-Quality Assessments (SWQAs) and are intended to complement drinking-water monitoring required by federal, state, and local programs, which focus primarily on post-treatment compliance monitoring. Through SWQAs, NAWQA is increasing its emphasis on characterizing rivers and aquifers that are major sources of drinking water and will continue to collaborate with other agencies and organizations involved with supplying and managing drinking water. Currently (2007), 15 ground-water SWQAs are in various stages of completion by NAWQA. This report focuses on a ground-water SWQA in the unconfined glacial stratified aquifer (fig. 2) in western and central Connecticut.

\footnotetext{
${ }^{1}$ Words in bold are defined in the Glossary at the back of this report.
} 


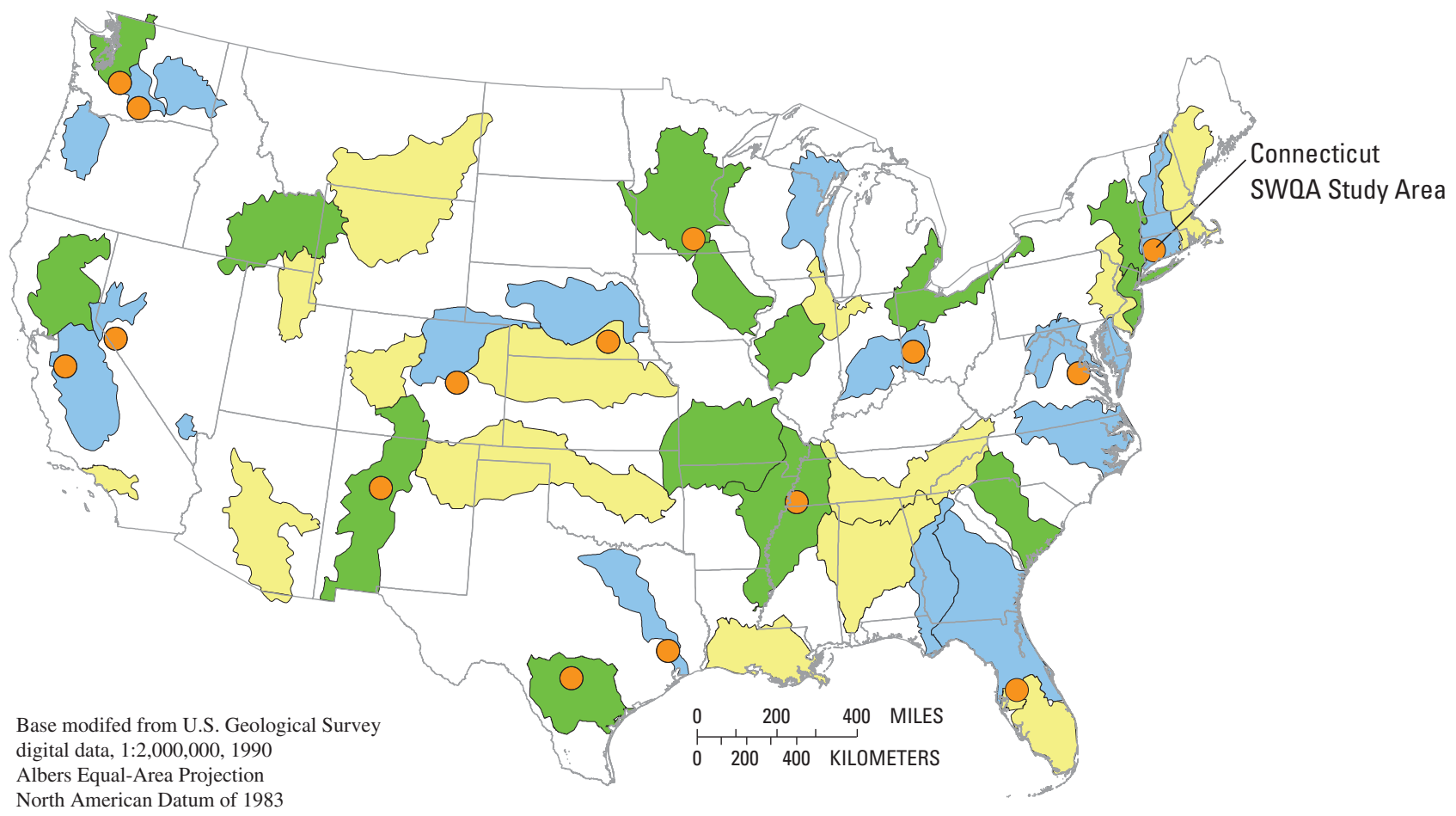

Albers Equal-Area Projection

North American Datum of 1983

\section{EXPLANATION}

NAWQA Study Units-Scheduled to begin in fiscal year: 2001

2004

2007
Ground-Water Source Water-Quality Assessment location

Figure 1. Location of National Water-Quality Assessment (NAWQA) study units and Ground-Water Source Water-Quality Assessment (SWOA) study areas.

Sampling for ground-water SWQAs consists of two phases. Phase I focuses on determining the occurrence of 258 anthropogenic organic compounds (AOCs) (Metz and others, 2006) in the source water of selected CWS wells in the NAWQA study units. Phase II focuses on those AOCs detected most frequently during Phase I of sampling and evaluates their detection frequencies and concentrations in source water and the associated finished water. As used in this study, source water is the raw (ambient) water collected at the supply well prior to water treatment, finished water is the source water or blended water that is treated and ready to be delivered to consumers, and blended water is a mixture of water from several ground-water sources. Finished water may be composed of water from multiple CWS wells (blended water) or it may be composed only of water from one CWS well and treated at (or near) the well (non-blended). Blended water, by definition, could include a mixture of ground water and surface water; however, for the purposes of this study (as well as other ground-water SWQAs) blended water refers only to blended ground water.
AOCs monitored as part of SWQAs include volatile organic compounds (VOCs), pesticides, and other anthropogenic organic compounds (OAOCs). VOCs are a subset of organic chemicals that have been produced and used in a variety of commercial, industrial, and household applications for many decades and are a major component or additive to gasoline, paints, varnishes, glues, dyes, and plastics (Zogorski and others, 2006). Pesticides are used extensively throughout the United States to increase crop yields; enhance the aesthetics of lawns, gardens, golf courses, and recreational areas; and to protect the safety of the public from insect-associated diseases. The widespread use of pesticides over the past several decades has led to their frequent detection in ground water (Barbash and Resek, 1996; Barbash and others, 1999). OAOCs represent a group of compounds that are present in a wide range of products commonly used in homes, industry, and agriculture, including personal-care and domestic-use products, plant- or animal-derived biochemicals, and fumigants. Little is known about the environmental occurrence, transport, and ultimate fate of OAOCs after their intended use; however, it is known 


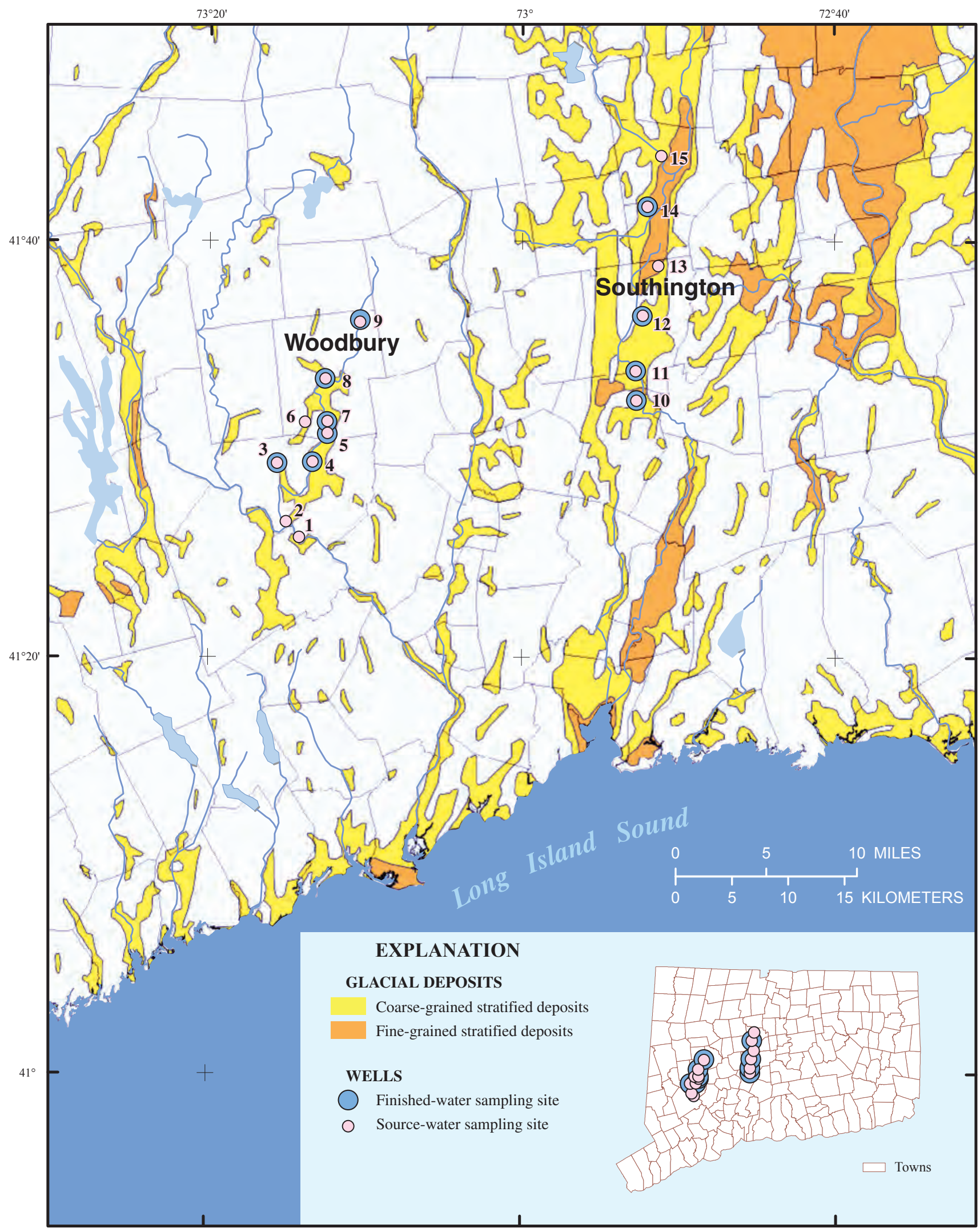

Base from U.S. Geological Survey, 1:24,000, 1969 to 1984 Connecticut State Plane projection

Glacial stratified deposits from USGS digital data, 1:1,000,000 DDS-38, 1998

Figure 2. Glacial stratified aquifer in western and central Connecticut and location of community water system wells sampled in Phase I (source water) and Phase II (source and finished water) of the Connecticut source water-quality assessment. 
that these compounds commonly are released directly to the environment after passing through wastewater treatment plants or domestic septic systems that often are not designed to remove these compounds from the effluent (Herberer, 2002; and Ternes and others, 2002). Until recently, few analytical methods were capable of detecting these compounds at the low concentrations that might be expected in the environment.

Data from most water-quality studies conducted by the USGS cannot be compared directly to data on the quality of source water from CWSs because of construction and pumping differences in the type of well sampled (such as monitoring and domestic wells). Consequently, a need exists to qualitatively determine if the results of these other studies are representative of the quality of source water used by large and very large CWSs. Similarly, because the application of various treatment technologies alters the chemistry of source water to meet federal and state drinking-water requirements, a need exists to better understand how representative source water is of finished water prior to distribution. Linking these types of studies is important, especially considering the documented occurrence of AOCs in finished water at concentrations similar to those found in source water (Loraine and Pettigrove, 2006; Stackelberg and others, 2004) and in simulated drinking-water treatment processes (Westerhoff and others, 2005). Thus, data obtained through SWQAs characterize not only the quality of source water and finished water of some of the larger CWSs prior to distribution, but also begin to provide a mechanism to bring results obtained from other studies into context with water used for human consumption.

\section{Purpose and Scope}

This report describes the occurrence of 258 AOCs in ground water sampled from $15 \mathrm{CWS}$ wells in western and central Connecticut during 2002-2004. Additionally, the report describes the detection frequency and concentrations of selected AOCs in samples from 10 of the 15 CWS wells and in the associated finished water. Concentrations are compared to U.S. Environmental Protection Agency (USEPA) Maximum Contaminant Levels (MCLs) and USGS Health-Based Screening Levels (HBSLs) to evaluate the potential relevance of the findings to human health.

\section{Ground-Water Withdrawals and Land Use in the Study Area}

Although the major cities in Connecticut rely on surface water for freshwater withdrawals for drinking-water supply, many surrounding towns rely mostly on ground water. Urban populations typically are concentrated in towns that overlie glacial aquifers in valleys. Of the 2.7 million people served by public water-supply systems in Connecticut, about 11 percent have publicly supplied (community supply) ground water as their source of drinking water. In addition, about 700,000 people in Connecticut drink water from domestic wells, and about 190,000 people drink ground water from non-community systems, such as schools and businesses (Starn and Stone, 2005). Glacial aquifers supply about 90 percent of public ground-water supply. Nearly all domestic wells obtain water from fractured bedrock.

Towns in the study area (fig. 2) have populations ranging from 9,200 in Woodbury to about 40,000 in Southington (U.S. Census Bureau, 2002). Since 1960, areas near the sampled wells have changed from primarily undeveloped or agricultural lands to residential, commercial, and industrial areas. Residential and commercial development tends to be more concentrated in the valleys, which overlie the glacial aquifers. Agricultural lands in the study area are limited; located mostly on flood plains, they produce silage corn, hay, and ornamental and bedding plants (fig. 3 ).

\section{Site Selection, Methods, and Human-Health Benchmarks}

This section describes the number of wells sampled, the selection process, and methods for sample collection and analyses. Regulated and non-regulated human-health benchmarks also are described, and a description of how water-quality results are interpreted in a human-health context is provided.

\section{Site Selection and Methods}

Fifteen wells (fig. 2) completed in the unconfined glacial stratified aquifer in western and central Connecticut were selected for sampling. Only CWS wells that are among the highest producing and deemed not to be under the direct influence of surface water were sampled. Sampled wells were at least $1 \mathrm{~km}$ apart to ensure that the contributing areas for the wells do not overlap. The "Surface Water Treatment Rule," enforced by the state of Connecticut, requires that all CWS wells satisfy criteria that indicate they are not under the direct influence of surface water. These criteria include source construction, separation distance, water quality, and history of disease outbreak. If a well fails to meet any of the criteria, the utility must perform a demonstration study, replace the source, reconstruct the source, or install treatment. Wells were sampled once from October 2002 through May 2003, and samples were analyzed for 88 VOCs, 120 pesticides, and 50 OAOCs (Metz and others, 2006).

During Phase II of the study, 10 of the 15 wells were resampled once in June or July 2004 based on the occurrence of AOCs detected most frequently in Phase I. Samples of both source water and associated finished water from 8 of the 10 wells were analyzed for VOCs, depending on the specific compounds; samples from 6 to 10 wells were analyzed for pesticides and OAOCs. All ground-water samples were collected using established USGS protocols (Koterba and 


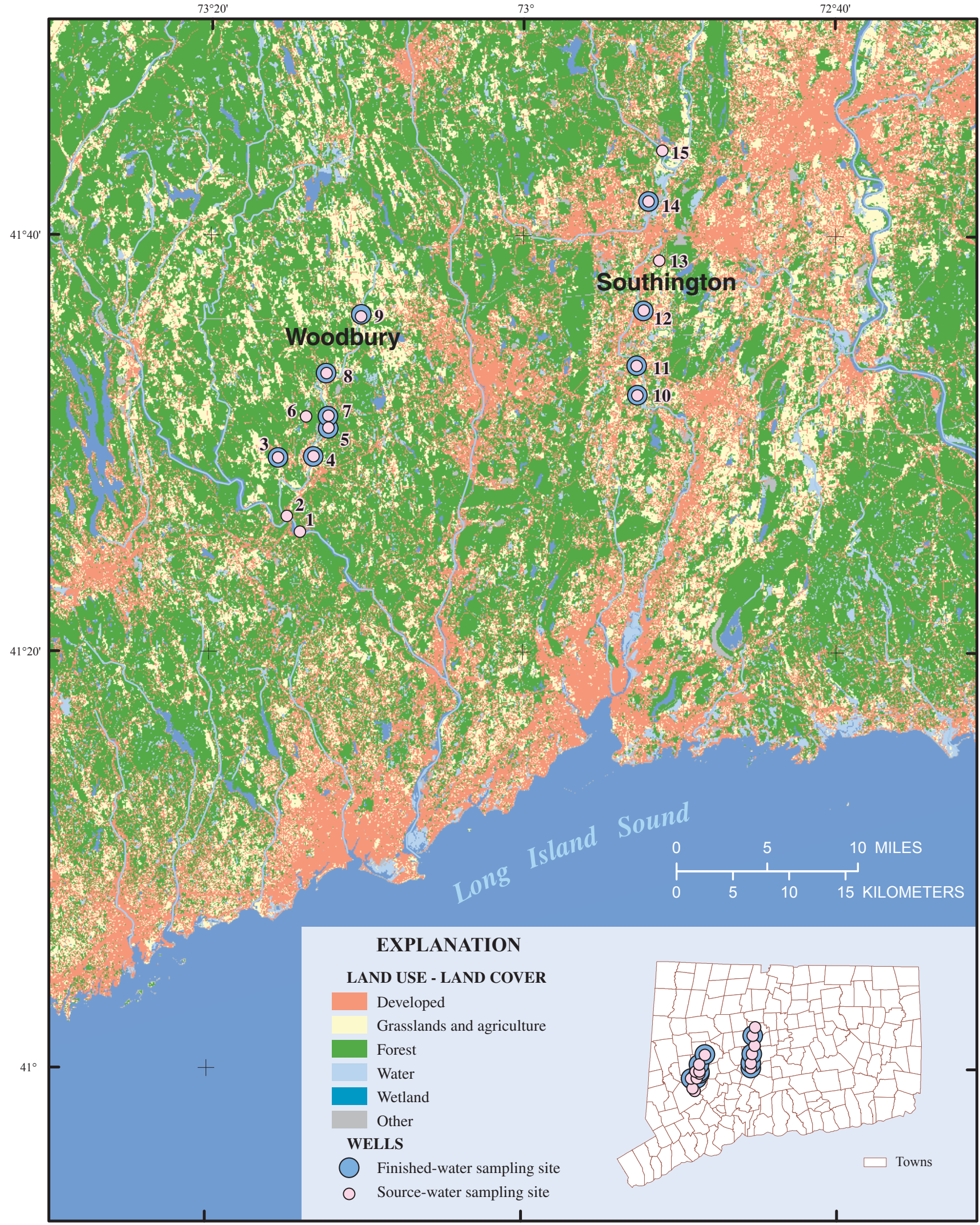

Figure 3. Land use in western and central Connecticut and location of community water system wells sampled in Phase I (source water) and Phase II (source and finished water) of the Connecticut source water-quality assessment. 
others, 1995). Finished-water samples were collected after treatment and prior to the entry to transport pipelines.

Samples were sent to the USGS National Water Quality Laboratory (NWQL) in Denver, Colorado, for analysis. For documentation pertaining to the analytical methods, see Zaugg and others (1995), Lindley and others (1996), Connor and others (1998), Furlong and others (2001), Sandstrom and others (2001), Zaugg and others (2002), and Madsen and others (2003). Some compounds were detected in 10 percent or more of NWQL laboratory set blanks. The contamination for these constituents can be characterized as random, as no systematic error was identified that affected sample results. Field and laboratory quality-control data suggest that, although a specific source cannot be identified, the quality of the environmental data for phenol is unknown; therefore, all phenol concentrations in samples were censored and removed from the data set. Similarly, N,N-diethyl-meta-toluamide (DEET) was detected at similar or greater detection frequency in blank samples than in environmental samples. Because of the uncertainty in the quality of DEET concentrations in environmental samples, all DEET data were censored and not used in any subsequent analyses.

In Phase II, a dechlorination reagent and, for some schedules, a pH buffer, were added to finished-water samples to reduce the degradation of organic compounds by converting free chlorine to chloride. A preliminary study was conducted by the NWQL to determine if SWQAs could begin using these reagents without any negative impact on the analytical performance. Results indicated that recoveries were not affected by the addition of these reagents (Mark Sandstrom, U.S. Geological Survey National Water Quality Laboratory, written commun., 2007); however, it has been established that the dechlorination reagents added to finished-water samples (specifically the $\mathrm{pH}$ buffer-Trizma) systematically contaminate samples with benzophenone, isophorone, and para-nonylphenol (Office of Water Quality Water-Quality Information Note 2007.04). Although the pH buffer only contaminated the finished-water data, all concentrations of benzophenone, isophorone, and para-nonylphenol were removed from the data set.

\section{Human-Health Benchmarks}

The USGS began an interagency pilot effort in 1998 to communicate the significance of water-quality findings of the NAWQA Program in a human-health context.

Historically, the USGS has assessed water-quality conditions by comparing water concentration data with human-health benchmarks, such as established federal or state drinkingwater standards and drinking-water guidelines. The drinking-water standards for regulated compounds are called maximum contaminant levels (MCLs), which protect drinking-water quality by limiting the concentration of specific compounds delivered to any user of a public water system that can adversely affect public health (U.S. Environmental Protection Agency, 2002). Drinking-water standards and guidelines do not exist, however, for nearly one-half of the compounds analyzed by the NAWQA Program and other USGS studies. Health-Based Screening Levels (HBSLs) are estimates of benchmark concentrations of contaminants in water that may be of potential human-health concern and are consistent with USEPA Office of Water methodologies for setting guidelines for nonenforceable drinking-water values. In order to provide a more complete understanding of the significance of water-quality data collected, existing federal drinking-water standards and guidelines are supplemented by HBSL concentrations or ranges calculated for unregulated compounds (compounds without federal drinking-water standards) monitored by the NAWQA Program using an approach that was developed collaboratively by the USGS, USEPA, New Jersey Department of Environmental Protection, and Oregon Health \& Science University (Toccalino and others, 2003, 2004).

HBSLs are not regulatory standards, are not enforceable, and water systems are not required to monitor for any unregulated compounds for which HBSLs have been developed. HBSLs can be used as thresholds against which contaminant concentrations in water can be compared to evaluate water-quality data in a human-health context. HBSLs can be used as planning tools to help prioritize contaminants that may merit further study or monitoring and to provide an early indication of contaminant concentrations of potential human-health concern in water resources (Toccalino and others, 2005). Descriptions of the human-health benchmarks that were used in this study can be seen in Metz and others (2006, appendix 4).

To aid in evaluating water-quality data in the context of human health, benchmark quotient (BQ) values were calculated. A BQ value is the ratio of a measured concentration of a detected compound to its MCL (for a regulated compound) or HBSL (for an unregulated compound). For this study, the maximum concentration detected for each compound was used to calculate this ratio, called BQmax. A BQmax value greater than or equal to 1.0 was used to identify concentrations of potential human-health concern (hereafter referred to as concentrations of potential concern). A BQmax threshold value greater than or equal to 0.1 was used to identify compounds that may warrant inclusion in a low-concentration, trends-monitoring program; frequently occurring compounds (in this report, frequently occurring indicates an occurrence of an $\mathrm{AOC}$ in 10 percent or more of samples) also may warrant inclusion in such a monitoring program. Such monitoring may provide an early indication of contaminant levels that approach human-health benchmarks, and consequently, concentrations of potential concern. 


\section{Consumer Confidence Reports and Source Water-Quality Assessments}

Since 1999, the U.S. Environmental Protection Agency (USEPA) has required water suppliers to provide annual drinking-water-quality reports called Consumer Confidence Reports (CCRs) to their customers (http:// www.epa.gov/safewater/ccr/ccrfact.html). CCRs are the centerpiece of the right-to-know provisions of the 1996 Amendments to the Safe Drinking Water Act. Each CCR provides consumers with fundamental information about their drinking water including (1) the source of the drinking water; (2) a brief summary of the susceptibility to contamination of the local drinking-water source; (3) the concentrations (or range of concentrations) of any contaminants found in local drinking water, as well as their USEPA maximum contaminant levels (MCLs), which are legally enforceable drinking-water standards and are the highest allowed concentrations of contaminants in drinking water, for comparison; and (4) phone numbers for additional sources of information.

Information in CCRs is specific to a particular water utility. Water utilities analyze finished-water samples primarily for regulated contaminants (that is, those with MCLs) using USEPA analytical methods for the purpose of compliance monitoring. In contrast, Source Water-Quality Assessments (SWQAs) performed by the USGS are not conducted for compliance monitoring, and encompass data from multiple water utilities spatially distributed across the Nation. As part of SWQAs, both source- and finished-water samples are analyzed using USGS analytical methods; source water is the raw (ambient) water collected at the surfacewater intake or supply well prior to water treatment, and finished water is the treated water sampled prior to entering the distribution system. USGS analytical methods used in SWQAs typically have lower analytical reporting levels than those used in compliance monitoring; contaminant detection frequencies reported in SWQA reports may therefore be higher than detection frequencies for the same contaminants reported in CCRs. In SWQAs, concentrations of regulated and unregulated contaminants in source and finished water are compared to MCLs and HBSLs, respectively.

\section{Anthropogenic Organic Compounds in Source Water}

\author{
A total of 25 of the 258 individual AOCs were
} detected (12 VOCs, 10 pesticides, and 3 OAOCs) in samples collected from 15 CWS wells sampled from October 2002 to May 2003 (table 1). The most frequently occurring AOCs were detected in more than half of the 15 source-water samples and included chloroform (87 percent of samples), methyl tert-butyl ether (MTBE, 80 percent), 1,1,1-trichloroethane (67 percent), atrazine (60 percent), deethylatrazine (60 percent), perchloroethene (PCE, 53 percent), and simazine (53 percent). Samples generally contained a mixture of compounds ranging from 2 to 19 detected compounds, with an average of about 8 compounds per sample.

Concentrations for compounds detected in the source water generally were low (less than $1.0 \mu \mathrm{g} / \mathrm{L}$ ); four compounds (fig. 4) were detected at higher concentrations in ground water from four wells. Human-health benchmarks were available for 17 of the 25 detected AOCs. Of these 17 compounds, two compounds, PCE and trichloroethene (TCE) had benchmark quotients greater than or equal to the 1.0 level that identifies concentrations of potential concern.

When comparing analytical results among different AOCs, it is important to consider the analytical reporting level of each AOC. That is, an AOC with a low reporting level may be detected more frequently when compared to other AOCs with higher reporting levels. A true comparison is possible, however, when comparing individual compounds analyzed using the same analytical method (same reporting level). For the purposes of this report, comparisons of AOCs are made among AOCs regardless of varying reporting levels (Metz and others, 2006) to characterize general occurrence rates and similarities, or the lack thereof, between AOCs.

\section{Volatile Organic Compounds}

Twelve VOCs were detected in the source-water samples (table 1, fig. 4A). Chloroform, the most frequently detected compound (87 percent of samples), occurred at low concentrations ranging from about $0.02 \mu \mathrm{g} / \mathrm{L}$ to $0.24 \mu \mathrm{g} / \mathrm{L}$. Chloroform is one of the four disinfection by-products (DBPs) produced in the highest concentrations during the chlorination of drinking water and wastewater. Other associated DBPs were detected much less frequently; bromodichloromethane was detected in only one sample and, dibromochloromethane and bromoform were not detected. The frequent detection of chloroform in the study area may be from several sources such as chlorinated or reclaimed water used to irrigate lawns and gardens; leakage from distribution lines for treated drinking water and wastewater, spas, and pools; and leachate 
Table 1. Detection frequency, maximum concentration, and maximum benchmark quotient value for anthropogenic organic compounds detected in 15 community water system wells sampled in Phase I (source water) of the Connecticut source water-quality assessment.

[MRL, Minimum Reporting Level; USEPA, U.S. Environmental Protection Agency; MCL, Maximum Contaminant Level; HBSL, Health-Based Screening Level; BQmax, Benchmark Quotient = ratio of maximum compound concentration to MCL or HBSL value; E, estimated value; $\mu \mathrm{g} / \mathrm{L}$, micrograms per liter; $<$, less than; --, not available; A regulated compound is a compound for which federal and(or) state drinking-water standards have been established; an unregulated compound is a compound for which no federal and(or) state drinking-water standards have been established]

\begin{tabular}{|c|c|c|c|c|c|c|c|c|}
\hline $\begin{array}{l}\text { Regulated (R) or unregulated (U) } \\
\text { compound }\end{array}$ & $\begin{array}{l}\text { Chemical } \\
\text { abstracts } \\
\text { service reg- } \\
\text { istry number }\end{array}$ & $\begin{array}{l}\text { Number of } \\
\text { samples } \\
\text { for source } \\
\text { water }\end{array}$ & $\begin{array}{c}\text { Number } \\
\text { of detec- } \\
\text { tions for } \\
\text { source } \\
\text { water }\end{array}$ & $\begin{array}{l}\text { Detection } \\
\text { frequency } \\
\text { (percent) }\end{array}$ & $\begin{array}{l}\text { MRL } \\
(\mu g / L)\end{array}$ & $\begin{array}{l}\text { Maximum } \\
\text { concentra- } \\
\text { tion for } \\
\text { source water } \\
\quad(\mu \mathrm{g} / \mathrm{L})\end{array}$ & $\begin{array}{c}\text { USEPA } \\
\text { MCL' or } \\
\text { HBSL }^{3} \\
(\mu \mathrm{g} / \mathrm{L})\end{array}$ & $\begin{array}{c}\text { BOmax } \\
\text { for source } \\
\text { water }\end{array}$ \\
\hline \multicolumn{9}{|c|}{ Volatile organic compounds } \\
\hline $1,1,1$-Trichloroethane $(\mathrm{R})$ & $71-55-6$ & 15 & 10 & 67 & 0.032 & 16.7 & 200 & 0.08 \\
\hline $\begin{array}{l}\text { 1,1,2-Trichloro-1,2,2- } \\
\text { Trifluoroethane (U) }\end{array}$ & $76-13-1$ & 15 & 2 & 13 & .038 & 1.06 & 200,000 & .000005 \\
\hline 1,1-Dichloroethane (U) & $75-34-3$ & 15 & 4 & 27 & .035 & 0.12 & -- & -- \\
\hline 1,1-Dichloroethene (R) & $75-35-4$ & 15 & 4 & 27 & .024 & .42 & 7 & .06 \\
\hline 1,2-Dichloropropane (R) & $78-87-5$ & 15 & 1 & 7 & .029 & E.02 & 5 & .004 \\
\hline Bromodichloromethane (R) & $75-27-4$ & 15 & 1 & 7 & .028 & E .04 & ${ }^{2} 80$ & .001 \\
\hline Chloroform (R) & $67-66-3$ & 15 & 13 & 87 & .024 & .24 & ${ }^{2} 80$ & .003 \\
\hline cis-1,2-Dichloroethene (R) & $156-59-2$ & 15 & 3 & 20 & .024 & .17 & 70 & .002 \\
\hline Methyl tert-butyl ether (MTBE) (U) & $1634-04-4$ & 15 & 12 & 80 & .1 & .8 & -- & -- \\
\hline Perchloroethene (PCE) (R) & $127-18-4$ & 15 & 8 & 53 & .03 & 5.47 & 5 & 1 \\
\hline Trichloroethene (TCE) (R) & $79-01-6$ & 15 & 7 & 47 & .038 & 15.9 & 5 & 3 \\
\hline Trichlorofluoromethane (U) & $75-69-4$ & 15 & 1 & 7 & .08 & E.04 & 2,000 & .00002 \\
\hline \multicolumn{9}{|c|}{ Pesticides } \\
\hline 1-Naphthol (U) & $90-15-3$ & 15 & 1 & 7 & .088 & E.01 & -- & -- \\
\hline Atrazine (R) & $1912-24-9$ & 15 & 9 & 60 & .007 & .022 & 3 & .007 \\
\hline Carbaryl (U) & $63-25-2$ & 15 & 1 & 7 & .018 & E. 01 & 4,000 & .000002 \\
\hline Deethylatrazine (U) & $6190-65-4$ & 15 & 9 & 60 & .014 & E.026 & -- & -- \\
\hline Deisopropylatrazine (U) & $1007-28-9$ & 15 & 3 & 20 & .08 & E.01 & -- & -- \\
\hline Imidacloprid (U) & $138261-41-3$ & 15 & 1 & 7 & .02 & .014 & 400 & .00004 \\
\hline Metalaxyl (U) & $57837-19-1$ & 15 & 1 & 7 & .007 & .009 & 600 & .00002 \\
\hline Metolachlor (U) & $51218-45-2$ & 15 & 5 & 33 & .006 & Е.007 & 70 & .0001 \\
\hline Prometon (U) & $1610-18-0$ & 15 & 4 & 27 & .01 & E .01 & 100 & .0001 \\
\hline Simazine (R) & $122-34-9$ & 15 & 8 & 53 & .005 & .008 & 4 & .002 \\
\hline \multicolumn{9}{|c|}{ Other anthropogenic organic compounds } \\
\hline $\begin{array}{l}\text { Acetyl hexamethyl tetrahydronaph- } \\
\text { thalene (AHTN) (U) }\end{array}$ & $21145-77-7$ & 14 & 1 & 7 & .5 & E.03 & -- & -- \\
\hline $\begin{array}{l}\text { Tri(2-chloroethyl)phosphate } \\
\text { (TCEP) (U) }\end{array}$ & $115-96-8$ & 14 & 1 & 7 & .5 & E.05 & -- & -- \\
\hline Triphenyl phosphate (U) & $115-86-6$ & 14 & 2 & 14 & .5 & E.07 & -- & -- \\
\hline
\end{tabular}

${ }^{1}$ U.S. Environmental Protection Agency (2006).

${ }^{2} \mathrm{MCL}$ is for total trihalomethanes.

${ }^{3}$ Denotes HBSL (Toccalino and others, 2005). 

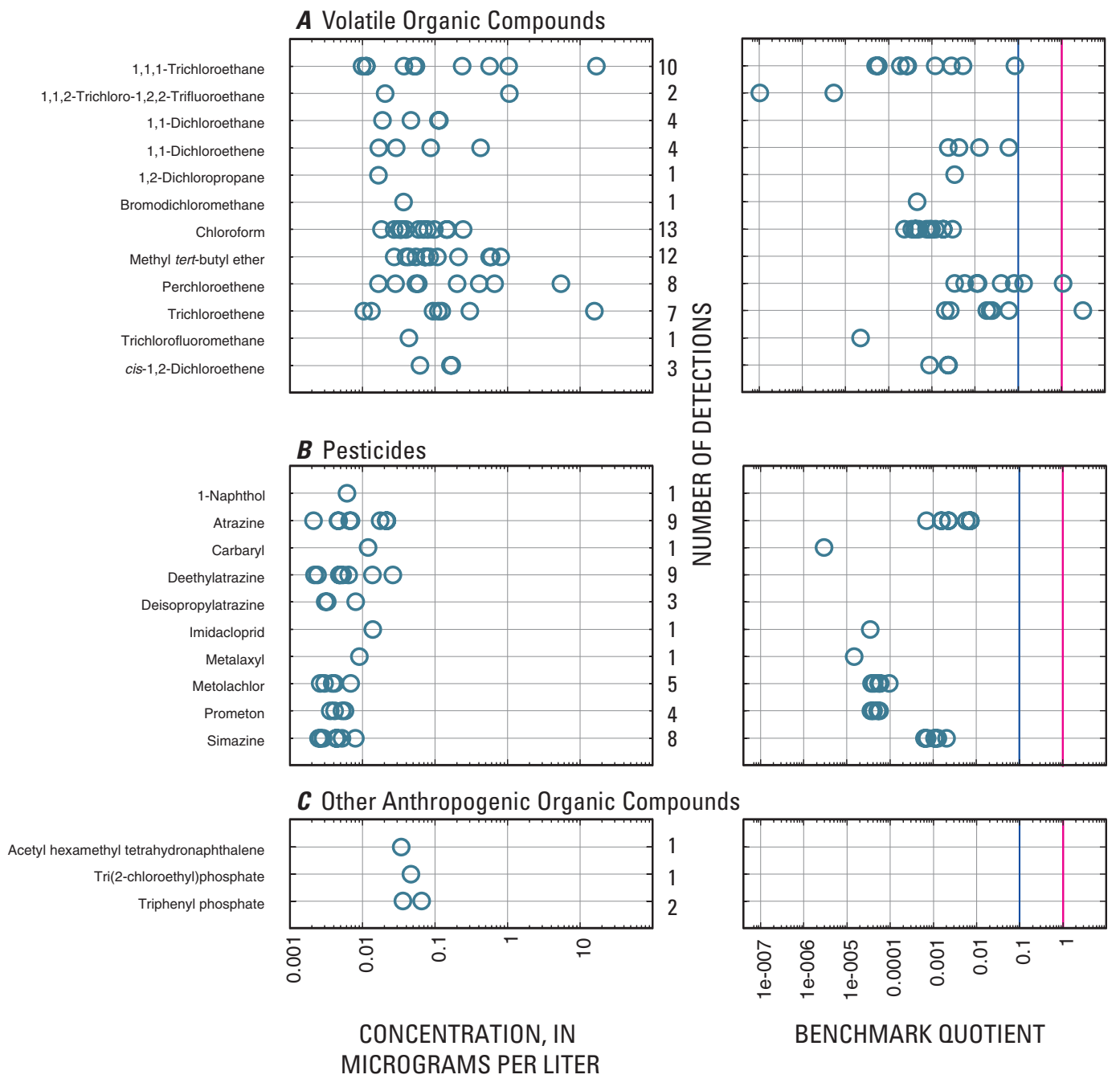

C Other Anthropogenic Organic Compounds

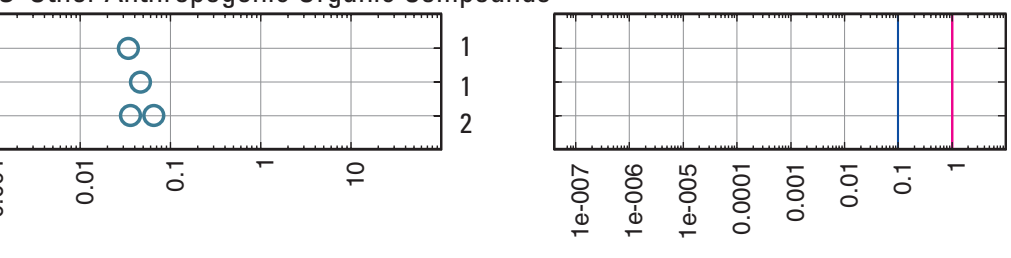

MICROGRAMS PER LITER

BENCHMARK QUOTIENT

\section{EXPLANATION}

Benchmark quotient value of $\mathbf{0 . 1}$-Values equal to or greater than this line may warrant inclusion of the compound in a low-concentration, trends-monitoring program

Benchmark quotient value of 1.0 - Values greater than this line indicate concentrations of potential human-health concern

\section{Source water}

Finished water-Some values are equal and therefore plotted values overlap

Non-blended

Blended

[Benchmark quotient value is the ratio of the detected concentration of a particular compound to its Maximum Contaminant Level, MCL; or Health-Based Screening Level, HBSL]

Figure 4. Concentration, number of detections, and benchmark quotient values for $(A)$ volatile organic compounds, $(B)$ pesticides, and $(C)$ other anthropogenic organic compounds detected in 15 community water system wells sampled in Phase I (source water) of the Connecticut source water-quality assessment. 
from septic-system drain fields (Thiros, 2000; Ivahnenko and Barbash, 2004; Zogorski and others, 2006). Other frequently detected VOCs include MTBE, a gasoline additive, and the solvents 1,1,1-trichloroethane, PCE, and TCE, which are commonly used as dry-cleaning agents.

Of the 12 VOCs detected, human-health benchmarks were available for 10 compounds (fig. 4A). BQmax values for these 10 VOCs typically were several orders of magnitude below 1, but those for two detections were greater than 1.0 (table 1). PCE had a BQmax value of 1 and TCE had a BQmax value of 3 indicating that these two compounds may be of potential concern. An HBSL was not available for MTBE or 1,1-dichloroethane because human-health toxicity information was not available.

\section{Pesticides}

Ten pesticide compounds were detected in the source water (table 1, fig. 4B). Although the number of individual pesticides detected (10) was roughly about the same as for VOCs (12), pesticides were detected less frequently in comparison to VOCs (43 pesticide detections compared to 66 VOC detections). Pesticides also were detected at much lower concentrations than VOCs (fig. 4B).

Of the 47 pesticide detections, most (77 percent) were derived from triazine herbicides; atrazine ( 9 detections) and its breakdown products deethylatrazine ( 9 detections), and deisopropylatrazine (3 detections) as well as simazine ( 8 detections) and prometon (4 detections). Several reasons exist for the high detection frequency for triazine herbicides, including high mobility in sandy soils, widespread use, and persistence in ground water (Kruger and others, 1995; Barbash and others, 1999). The half-life for atrazine in soils can be more than 100 days, and in ground water, atrazine and deethylatrazine can persist for almost 6 years and more than 25 years, respectively (Denver and Sandstrom, 1991; Gaus, 2000).

Of the 10 pesticides detected, human-health benchmarks were available for 7 of these compounds (table 1, fig. 4B). BQmax values for these seven pesticides typically were several orders of magnitude below 1.0 and none were greater than 0.1 (table 1). Atrazine had the highest calculated BQ value of 0.007 .

\section{Other Anthropogenic Organic Compounds}

Three OAOCs were detected in the source-water samples-acetyl hexamethyl tetrahydronaphthalene (AHTN), tri(2-chloroethyl)phosphate, and triphenyl phosphate-and concentrations were low (table 1, fig. 4C). Triphenyl phosphate had the highest detected concentration, estimated at $0.07 \mu \mathrm{g} / \mathrm{L}$. None of the three OAOCs detected have associated human-health benchmark values available.

\section{Anthropogenic Organic Compounds in Source and Associated Finished Water}

Ten of the original 15 CWS wells with AOC detections were resampled during the Phase II of this study along with their associated finished water during June or July 2004. Of the 10 finished-water sources sampled, 3 were blended with water from other CWS wells, and 7 were not blended. Because water from these CWSs was analyzed only for those AOCs that occurred most frequently during the first phase of sampling, not all pairs of CWS wells and associated finished water were sampled the same number of times for the same AOCs. That is, 8 pairs of source-water and associated finished-water samples were analysed for VOCs, 8 to 10 pairs were analyzed for pesticides, and 8 source-water and 9 finished-water samples were analyzed for OAOCs. Three of the finished-water samples represented water blended with water from other CWS wells prior to treatment, and five were not blended. Generally, where eight finished-water samples were collected, three were from blended sources and five were not blended.

Because the process used to select CWS wells in Phase II was biased to those compounds that occurred most frequently, and because this process resulted in a small number of samples, characterization of the overall occurrence of these compounds in source water and finished water is not feasible. Consequently, a general comparison of these compounds in source water and finished water is presented. For interpretive purposes, selected finished-water results were separated into blended and non-blended waters. This differentiation provides additional insight into the effect of blending on finished-water quality and allows for examination of occurrence findings separately for CWSs that do not blend with those that do blend. Concentrations of each AOC detected in source water and the associated blended or non-blended finished water are presented in appendix 1.

\section{Volatile Organic Compounds}

A total of 19 VOCs were detected in either the source water or the finished water (table 2; appendix 1). Specifically, four VOCs were detected only in source water, four only in finished water, and 11 VOCs were detected in both sourceand finished-water samples (table 2, fig. 5). DBPs accounted for most of the VOC detections, with all concentrations less than $1 \mu \mathrm{g} / \mathrm{L}$ and benchmark quotient values less than 0.01 . DBPs are regulated by the USEPA with an MCL of $80 \mu \mathrm{g} / \mathrm{L}$ for the sum of all four compounds (U.S. Environmental Protection Agency, 2006). Chloroform, the most frequently detected VOC, was detected in all source- and finished-water samples. Bromoform was undetected in source-water samples; however, it was detected in four finished-water samples. Dibromochloromethane was undetected in all source-water samples and detected in five finished-water samples, one of which was from blended sources. 


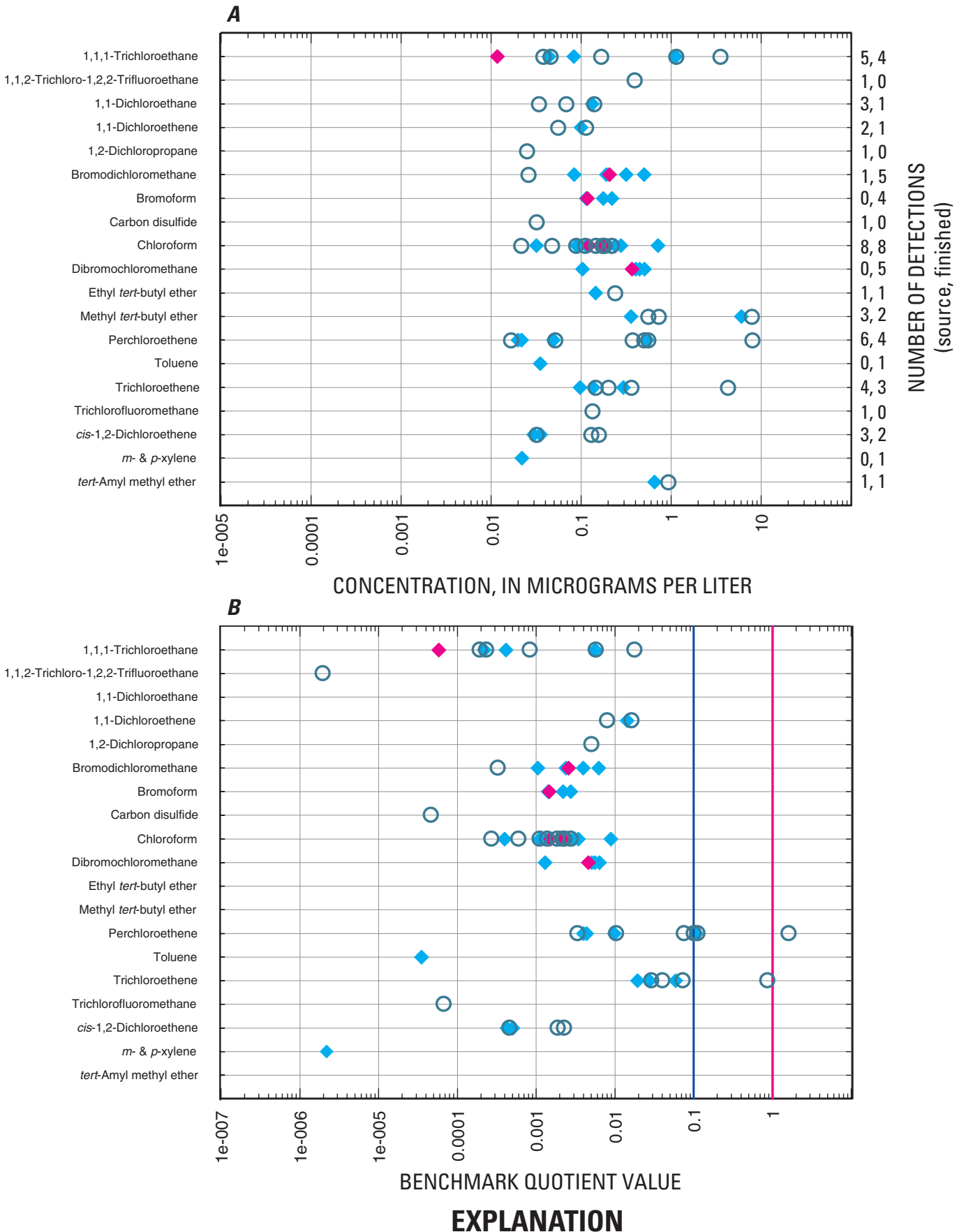

Benchmark quotient value of $\mathbf{0 . 1}$-Values equal to or greater than this line may warrant inclusion of the compound in a low-concentration, trends-monitoring program

Benchmark quotient value of 1.0 - Values greater than this line indicate concentrations of potential human-health concern
Source water

Finished water-Some values are equal and therefore plotted values overlap

Non-blended

$\checkmark$ Blended

[Benchmark quotient value is the ratio of the detected concentration of a particular compound to its Maximum Contaminant Level, MCL; or Health-Based Screening Level, HBSL]

Figure 5. (A) Concentrations and number of detections and $(B)$ benchmark quotient values for volatile organic compounds detected in 10 community water system wells sampled in Phase II (source and finished water) of the Connecticut source water-quality assessment. 


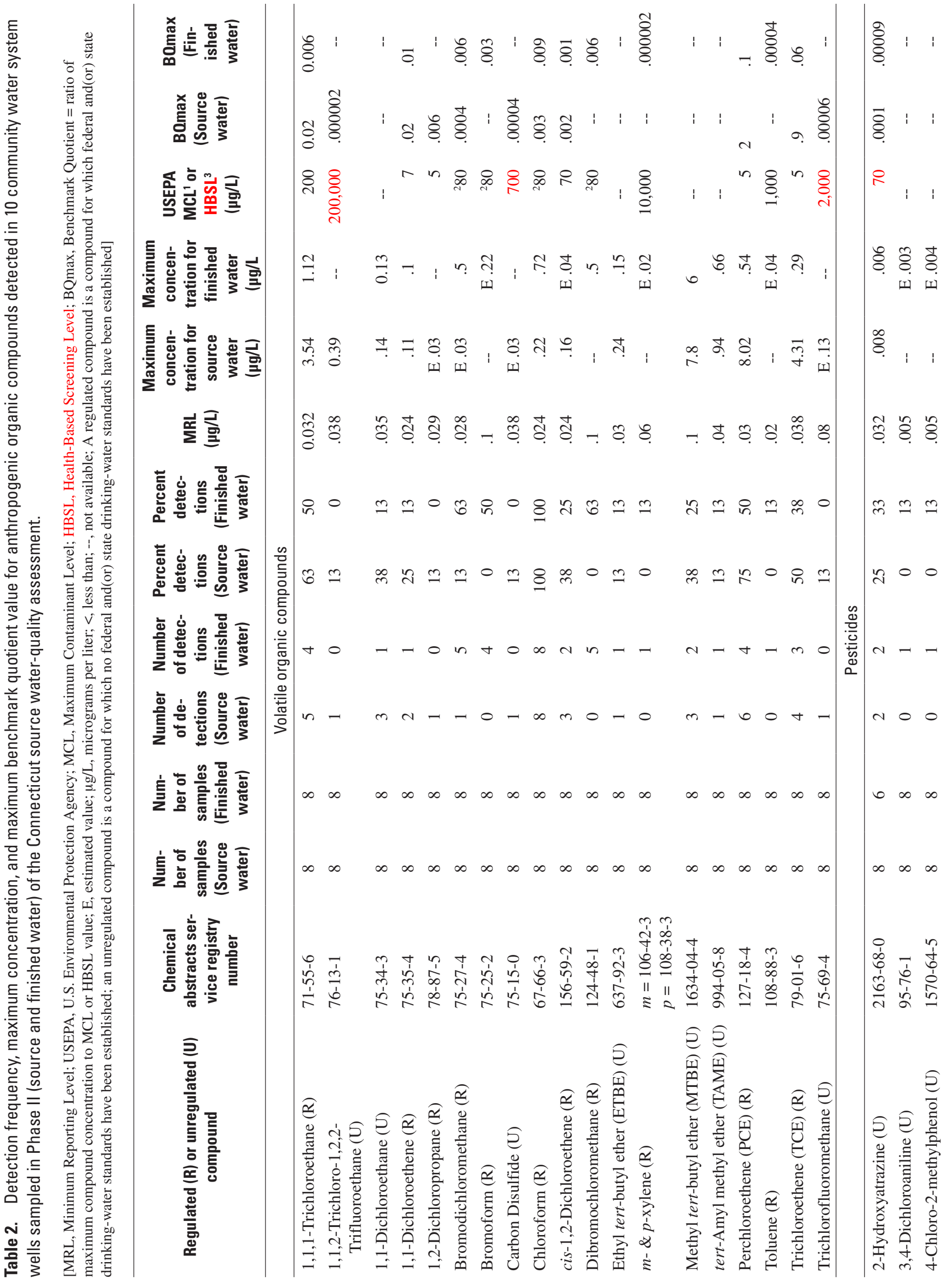




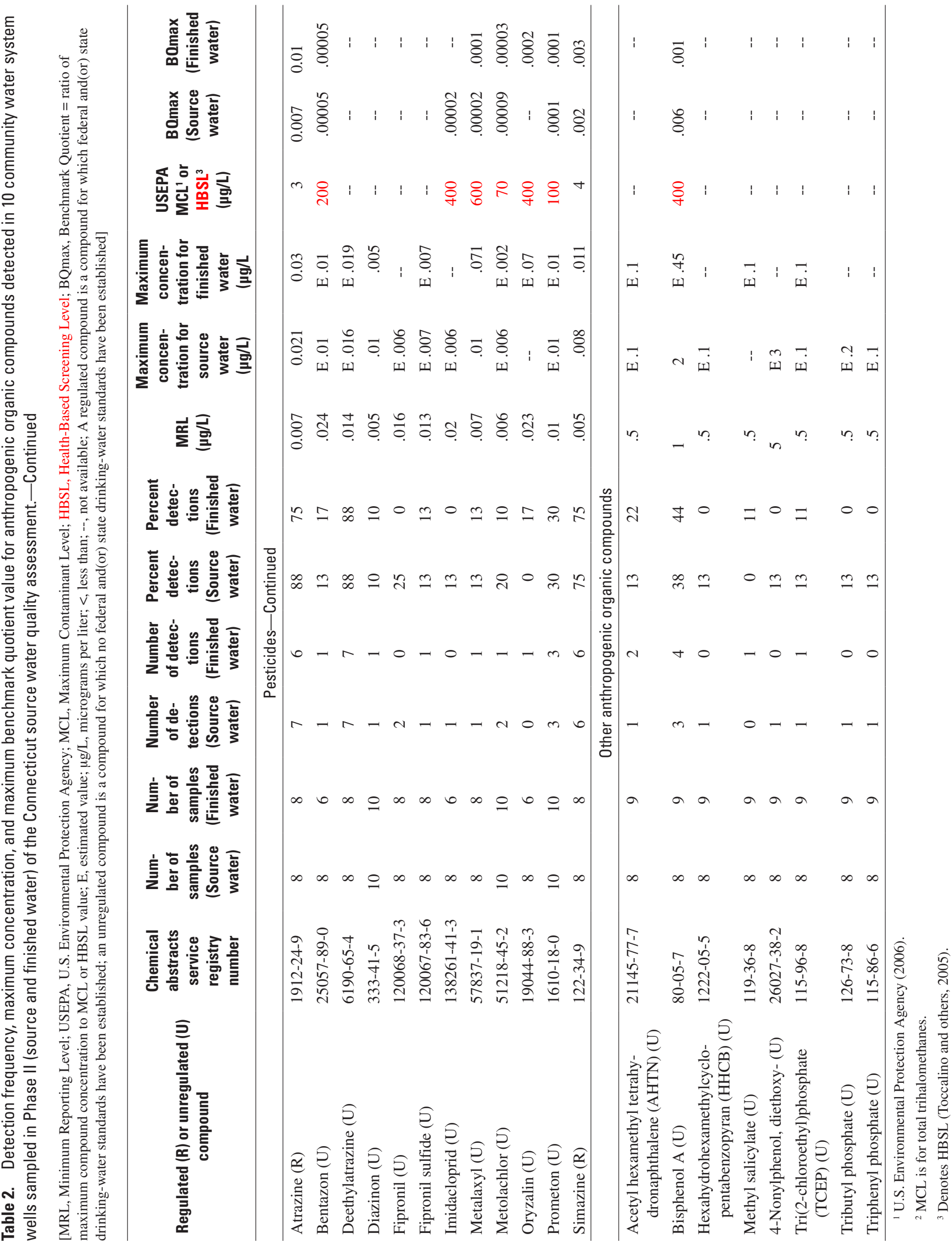


Other detected VOCs included 1,1,1-trichloroethane, which was detected in five source-water samples and four finished-water samples. The maximum concentration was $3.54 \mu \mathrm{g} / \mathrm{L}$ in source water and $1.12 \mu \mathrm{g} / \mathrm{L}$ in finished water. Of the five source-water detections, three also were detected in the associated finished water. This compound in one finishedwater sample from blended sources was undetected in the associated source-water sample. MTBE was detected in three source-water samples with a maximum concentration of $7.8 \mu \mathrm{g} / \mathrm{L}$ and was detected in two finished-water samples with a maximum concentration of $6.0 \mu \mathrm{g} / \mathrm{L}$.

The solvents PCE and TCE had the highest calculated benchmark quotients of any VOC. PCE was detected in six source-water samples with a maximum concentration of $8.02 \mu \mathrm{g} / \mathrm{L}$ and a BQ value of 2 and two measured concentrations greater than $0.5 \mu \mathrm{g} / \mathrm{L}$ and $\mathrm{BQ}$ values greater than 0.1 . PCE also was detected in four finished-water samples, one of which had a concentration of $0.54 \mu \mathrm{g} / \mathrm{L}$ and a BQ value of 0.1 . TCE was detected in four source-water samples, one of which had a concentration of $4.31 \mu \mathrm{g} / \mathrm{L}$ with a BQ value of 0.9 ; however, the highest of three detections in finished water was only $0.29 \mu \mathrm{g} / \mathrm{L}$ with a BQ value of 0.06 .

\section{Pesticides}

A total of 15 pesticides were detected in either the source water or the associated finished water (table 2; appendix 1). Most pesticide detections were triazine herbicides (table 2, fig. 6) or their degradation products, including atrazine and deethylatrazine, which were detected in most source- and finished-water samples. 2-Hydroxyatrazine was detected in both source- and finished water at one site, in source water at one site where the finished water was not sampled, and in finished water at one site where the water was from a blended source. Deethylatrazine was detected in both source- and finished-water samples at seven sites, prometon in three source samples and their associated finished water samples, and simazine in six source samples and their associated finished water. Of 34 pesticide detections in source water and 32 detections in finished water, 27 were in both the source water and the associated finished water. The highest BQ value of 0.01 for a triazine herbicide was from a blended-source finished-water sample for atrazine (appendix 1).

Diazinon and metalaxyl are also of interest because they were detected above the MRL in one sample each in both source water and the associated finished water.

\section{Other Anthropogenic Organic Compounds}

Eight OAOCs were detected in source or finished water (table 2, fig. 7, appendix 1): acetyl hexamethyl tetrahydronaphthalene, bisphenol A, hexahydrohexamethylcyclypentabenzopyran (HHCB), methyl salicylate, tri(2-chloroethyl) phosphate, tributyl phosphate, and triphenyl phosphate. All concentrations were low. Bisphenol A was the most frequently detected OAOC, with three detections in source water and four in finished water. It was the only detected OAOC with an associated Benchmark Quotient, with a maximum BQ value of 0.006, well below levels of potential concern. 


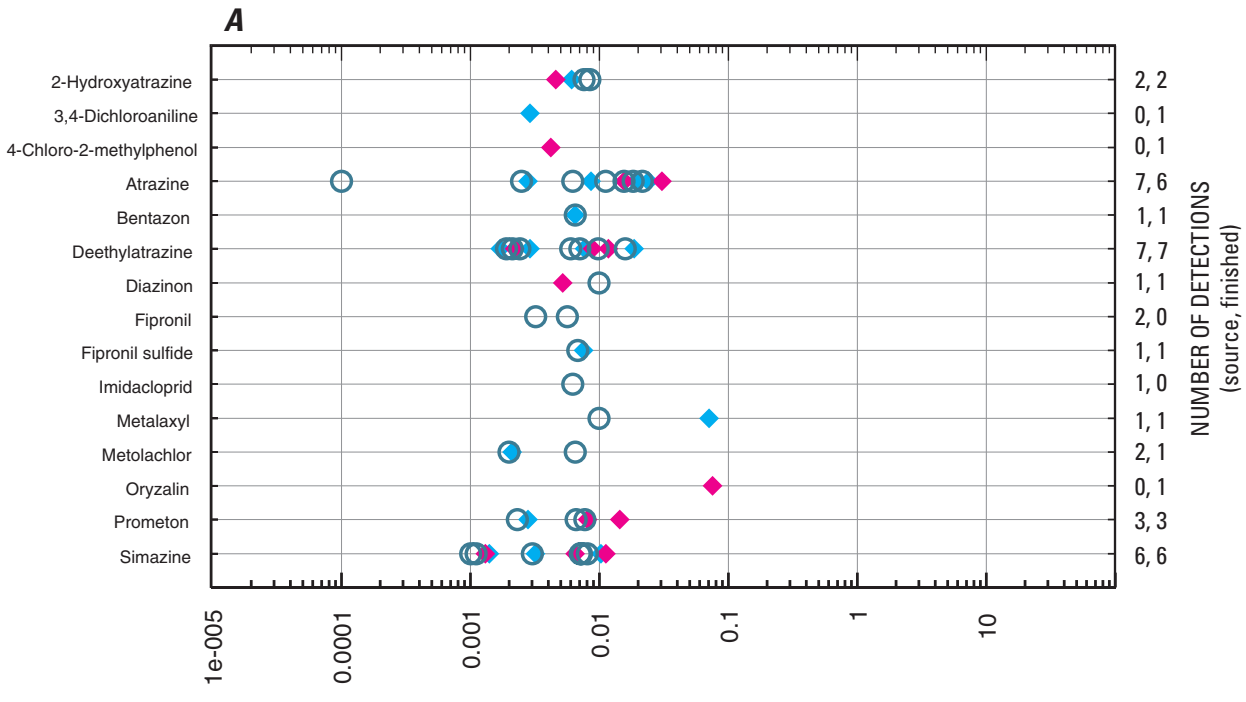

CONCENTRATION, IN MICROGRAMS PER LITER

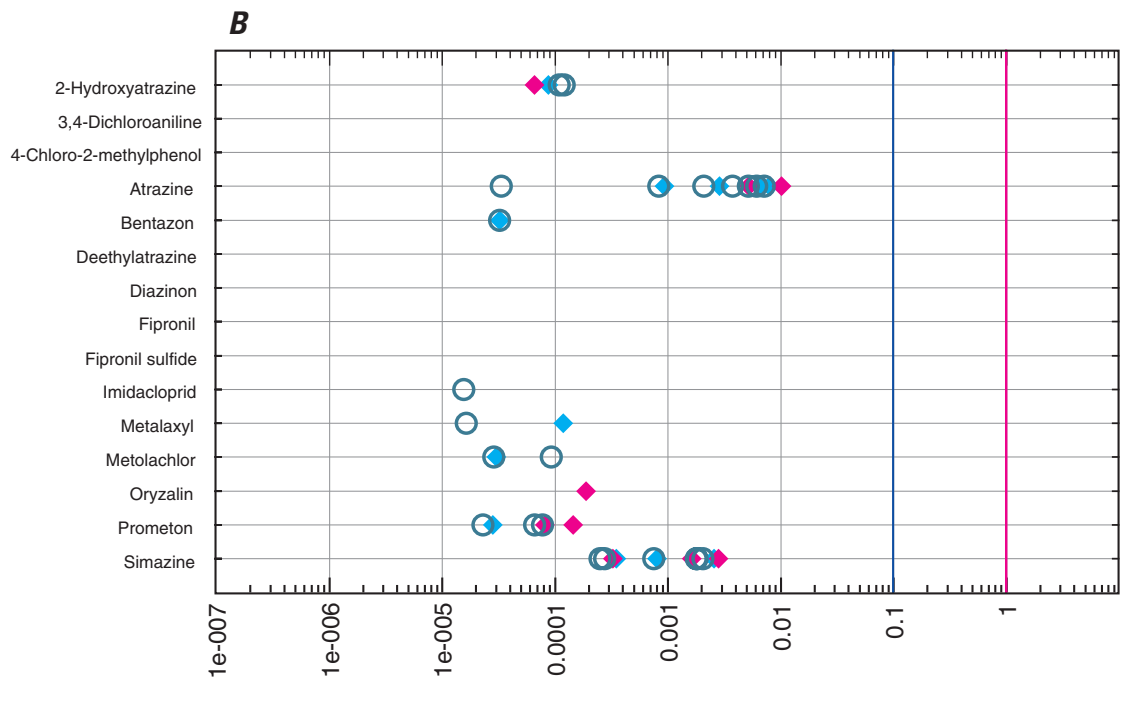

BENCHMARK QUOTIENT VALUE

\section{EXPLANATION}

Benchmark quotient value of $0.1-$ Values equal

to or greater than this line may warrant

inclusion of the compound in a low-concentration, trends-monitoring program

Benchmark quotient value of 1.0 - Values greater than this line indicate concentrations of potential human-health concern

\section{O Source water}

Finished water-Some values are equal and therefore plotted values overlap

$\checkmark$ Non-blended

Blended

[Benchmark quotient value is the ratio of the detected concentration of a particular compound to its Maximum Contaminant Level, MCL; or Health-Based Screening Level, HBSL]

Figure 6. (A) Concentrations and number of detections and $(B)$ benchmark quotient values for pesticides detected in 10 community water system wells sampled in Phase II (source and finished water) of the Connecticut source water-quality assessment. 


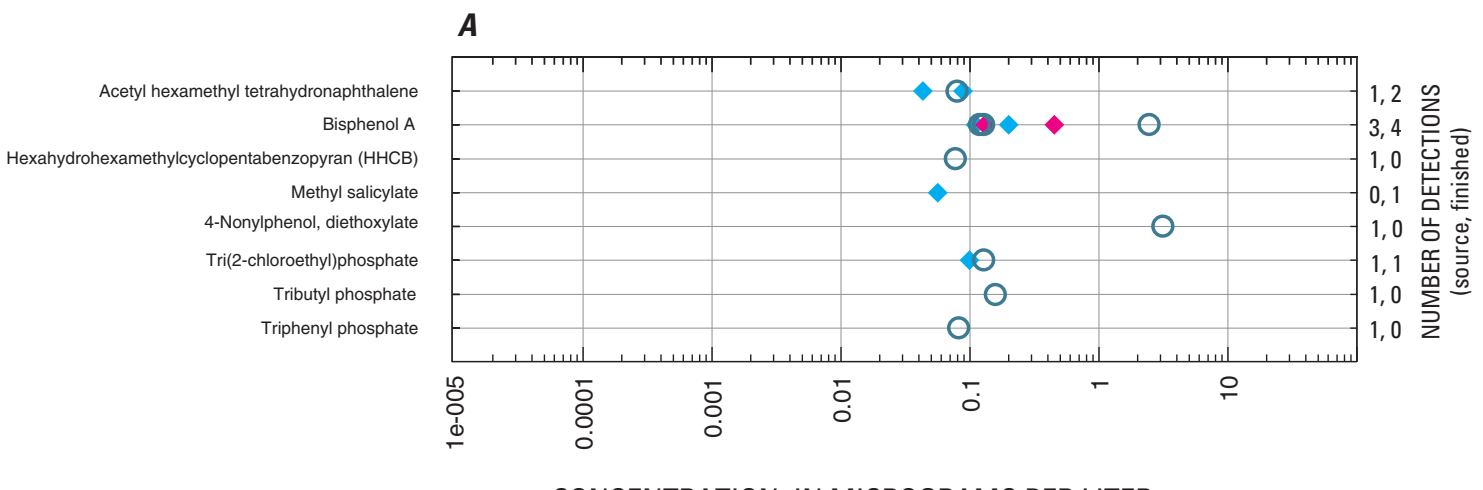

CONCENTRATION, IN MICROGRAMS PER LITER

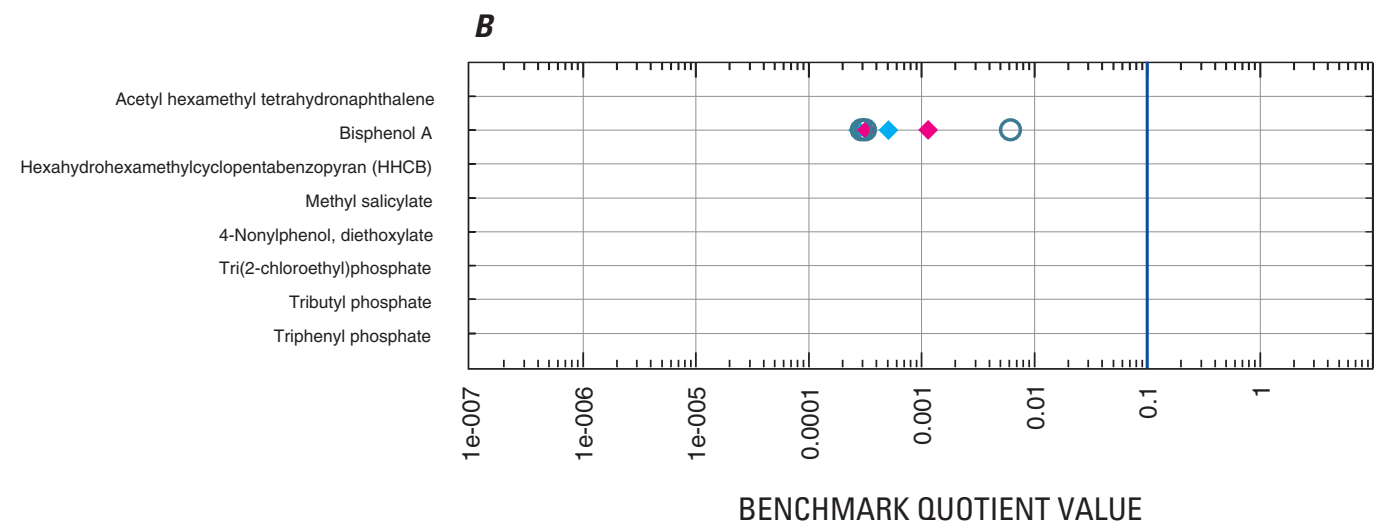

\section{EXPLANATION}

Benchmark quotient value of $\mathbf{0 . 1}$-Values equal to or greater than this line may warrant inclusion of the compound in a low-concentration, trends-monitoring program

Benchmark quotient value of 1.0 - Values greater than this line indicate concentrations of potential human-health concern

\section{Source water}

Finished water-Some values are equal and therefore plotted values overlap

Non-blended

Blended

[Benchmark quotient value is the ratio of the detected concentration of a particular compound to its Maximum Contaminant Level, MCL; or Health-Based Screening Level, HBSL]

Figure 7. ( $A$ ) Concentrations and number of detections and $(B)$ benchmark quotient values for other anthropogenic organic compounds detected in 10 community water system wells sampled in Phase II (source and finished water) of the Connecticut source water-quality assessment. 


\section{Summary}

The U.S. Geological Survey conducted a source waterquality assessment (SWQA) study of ground water sampled from community water system (CWS) wells in western and central Connecticut. Fifteen CWS wells, screened in the unconfined glacial stratified aquifer, were sampled during Phase I of the study during 2002-2004 to determine the occurrence of 258 anthropogenic organic compounds (AOCs). During Phase II of the study, samples from 10 of the original 15 wells along with samples of the associated finished water were collected in June or July 2004 to compare the detection frequency and concentration of selected AOCs between source and finished water.

During Phase I of the study, 25 individual AOCs were detected (12 volatile organic compounds (VOCs), 10 pesticides, and 3 other anthropogenic organic compounds (OAOCs)). The most frequently occurring AOCs were detected in more than half of the 15 source-water samples and included chloroform (87 percent), methyl tert-butyl ether (MTBE, 80 percent), 1,1,1-trichloroethene (67 percent), atrazine (60 percent) deethylatrazine (60 percent), perchloroethene (PCE, 53 percent), and simazine (53 percent). Samples generally contained a mixture of compounds ranging from 2 to 19 detected compounds, with an average of about 8 compounds per sample. Concentrations for compounds detected in the source water generally were low; four compounds were detected at concentrations of 1 microgram per liter $(\mu \mathrm{g} / \mathrm{L})$ or greater in water from four wells.

Ten of the original $15 \mathrm{CWS}$ wells that had AOC detections were resampled during Phase II of this SWQA along with the associated finished water. A total of 19 VOCs were detected in either the source water or the finished water. Disinfection by-products of trihalomethane accounted for most of the VOC detections, with all concentrations less than $1 \mu \mathrm{g} / \mathrm{L}$ and benchmark quotient values less than 0.01. Chloroform, the most frequently detected VOC, was detected in all source- and finished-water samples. Other detected VOCs included MTBE, a gasoline additive, and the solvents 1,1,1-trichloroethane, perchloroethene (PCE) and trichloroethene (TCE). Most of the detected pesticides were triazine herbicides such as atrazine or their degradation products, which were detected in most source- and finishedwater samples. Eight OAOCs were detected in source or finished water samples at low concentrations.

\section{Acknowledgments}

We are grateful to the many public and private organizations for providing information pertaining to the wells used in this study and for permitting the collection of water samples for analyses. In particular, we wish to thank the water managers and engineers for Woodbury Place, Woodlake Tax District, United Water Company, Watertown Fire District,
Oakdale Manor, Aquarion Water of Connecticut, Southbury Training School, Heritage Village, Unionville Water Company, Southington Water Company, and South Central Regional Water Authority.

\section{References Cited}

Barbash, J.E., Thelin, G.P., Kolpin, D.W., and Gilliom, R.J., 1999, Distribution of major herbicides in ground water of the United States: U.S. Geological Survey Water-Resources Investigations Report 98-4245, 57 p.

Barbash, J.E., and Resek, E.A., 1996, Pesticides in ground water-Distribution, trends, and governing factors: Chelsea, Mich., Ann Arbor Press, Pesticides in the Hydrologic System Series, v. 2, 590 p.

Connor, B.F., Rose, D.L., Noriega, M.C., Murtagh, L.K., and Abney, S.R., 1998, Methods of analysis by the U.S. Geological Survey National Water Quality Laboratory-Determination of 86 volatile organic compounds in water by gas chromatography/mass spectrometry, including detections less than reporting limits: U.S. Geological Survey OpenFile Report 97-829, 78 p.

Denver, J.M., and Sandstrom, M.W., 1991, Distribution of dissolved atrazine and two metabolites in the unconfined aquifer, southeastern Delaware, in Mallard, G.E., and Aronson, D.A., eds., U.S. Geological Survey Toxic Substances Hydrology Program-Proceedings of the technical meeting, Monterey, Calif., March 11-15, 1991: U.S. Geological Survey Water-Resources Investigations Report 91-4034, p. 314-318.

Furlong, E.T., Anderson, B.D., Werner, S.L., Soliven, P.P., Coffey, L.J., and Burkhardt, M.R., 2001, Methods of analysis by the U.S. Geological Survey National Water Quality Laboratory-Determination of pesticides in water by graphitized carbon-based solid-phase extraction and high-performance liquid chromatography/mass spectrometry: U.S. Geological Survey Water-Resources Investigations Report 01-4134, 73 p.

Gaus, Irena, 2000, Effects of water extraction in a vulnerable phreatic aquifer-Consequences for groundwater contamination by pesticides, Sint-Jansteen area, The Netherlands: Journal of Hydrology, v. 8, p. 218-229.

Herberer, Thomas, 2002, Occurrence, fate, and removal of pharmaceutical residues in the aquatic environmentA review of recent research data: Toxicology Letters, v. 131, p. 5-17. 
Ivahnenko, Tamara, and Barbash, J.E., 2004, Chloroform in the hydrologic system-Sources, transport, fate, occurrence, and effects on human health and aquatic organisms: U.S. Geological Survey Scientific Investigations Report 2004-5137, 34 p.

Koterba, M.T., Wilde, F.D., and Lapham, W.W., 1995, Ground-water-data-collection protocols and procedures for the National Water-Quality Assessment Program collection and documentation of water quality samples and related data: U.S. Geological Survey Open-File Report 95-399, $113 \mathrm{p}$.

Kruger, E.L., Zhu, Beilei, and Coats, J.R., 1995, Relative mobilities of atrazine, five atrazine degradates, metolachlor, and simazine in soils of Iowa: Environmental Toxicology and Chemistry, v. 15, no. 5, p. 691-695.

Lindley, C.E., Stewart, J.T., and Sandstrom, M.W., 1996, Determination of low concentrations of acetochlor in water by automated solid-phase extraction and gas chromatography with mass selective detection: Journal of Association of Official Analytical Chemists International, v. 79, no. 4, p. 962-966.

Loraine, G.A., and Pettigrove, M.E., 2006, Seasonal variations in concentrations of pharmaceuticals and personal care products in drinking water and reclaimed wastewater in southern California: Environmental Science and Technology, v. 40, p. 687-695.

Madsen, J.E., Sandstrom, M.W., and Zaugg, S.D., 2003, Methods of analysis by the U.S. Geological Survey National Water Quality Laboratory-A method supplement for the determination of fipronil and degradates in water by gas chromatography/mass spectrometry: U.S. Geological Survey Open-File Report 02-462, 11 p.

Metz, P.A., Delzer, G.C., Berndt, M.P., Crandall, C.A., and Toccalino, P.L., 2007, Anthropogenic organic compounds in ground water and finished water of community water systems in the northern Tampa Bay area, Florida, 2002-04: U.S. Geological Survey Scientific Investigations Report 2006-5267, 48 p.

Sandstrom, M.W., Stroppel, M.E., Foreman, W.T., and Schroeder, M.P., 2001, Methods of analysis by the U.S. Geological Survey National Water Quality LaboratoryDetermination of moderate-use pesticides and selected degradates in water by $\mathrm{C}-18$ solid-phase extraction and gas chromatography/mass spectrometry: U.S. Geological Survey Water-Resources Investigations Report 01-4098, 70 p.

Stackelberg, P.E., Furlong, E.T., Meyer, M.T., Zaugg, S.D., Henderson, A.K., Reissman, D.B., 2004, Persistence of pharmaceutical compounds and other organic wastewater contaminants in a conventional drinking-water-treatment plant: Science of the Total Environment, v. 329, no. 1-3, p. 99-113.
Starn, J.J., and Stone, J.R., 2005, Simulation of groundwater flow to assess geohydrologic factors and their effect on source-water areas for bedrock wells in Connecticut: U.S. Geological Survey Scientific Investigations Report 2004-5132, 78 p., online only at http://pubs.usgs.gov/ sir/2004/5132/

Ternes, T.A., Meisenheimer, M., McDowell, D., Sacher, F., Branch, H.J., Hsiate-Guide, B., Preuss, G., Wilme, U., and Zulei-Seibert, N., 2002, Removal of pharmaceuticals during drinking water treatment: Environmental Science and Technology, v. 36, p. 3855-3863.

Thiros, S.A., 2000, Quality of shallow ground water in areas of recent residential and commercial development in Salt Lake Valley, Utah, 1999: U.S. Geological Survey Fact Sheet 106-00, 6 p.

Toccalino, P.L., Norman, J.E., Phillips, R.H., Kauffman, L.J., Stackelberg, P.E., Nowell, L.H., Krietzman, S.J., and Post, G.B., 2004, Application of health-based screening levels to ground-water quality data in a state-scale pilot effort: U.S. Geological Survey Scientific Investigations Report 2004-5174, 64 p.

Toccalino, P.L., Nowell, Lisa, Wilber, W.G., Zogorski, J.S., Donohue, Joyce, Eiden, Catherine, Krietzman, S.J., and Post, G.B., 2003, Development of health-based screening levels for use in State- or local-scale water-quality assessments: U.S. Geological Survey Water-Resources Investigations Report 03-4054, 22 p.

Toccalino, P.L., Zogorski, J.S., and Norman, J.E., 2005, Health-based screening levels and their application to water-quality data: U.S. Geological Survey Fact Sheet 2005-3059, 2 p.

U.S. Census Bureau, 2002, 2000 census of population and housing, summary population and housing characteristics: Washington, D.C., Bureau of the Census, publication PHC-1-8, Connecticut, 87 p., at http://www.census.gov/ prod/cen2000/phc-1-8.pdf

U.S. Environmental Protection Agency, 2002, Setting standards for safe drinking water: U.S. Environmental Protection Agency, Office of Ground Water and Drinking Water: Washington, D.C., updated November 26, 2002, accessed January 7, 2005, at http://www.epa.gov/safewater/standard setting.htm

U.S. Environmental Protection Agency, 2006, Title 40Protection of Environment, Chapter I Environmental Protection Agency, Part 141-National primary drinking water regulations: Washington, D.C., at http://www.access.gpo. gov/nara/cfr/waisidx_02/40cfr141_02.html 
Westerhoff, Paul, Yoon, Yeomin, Snyder, Shane, Wert, Eric, 2005, Fate of endocrine-disruptor, pharmaceutical, and personal care product chemicals during simulated drinking water treatment processes: Environmental Science and Technology, v. 39, no. 17, p. 6649-6663.

Zaugg, S.D., Smith, S.G., Schroeder, M.P., Barber, L.B., and Burkhardt, M.R., 2002, Methods of analysis by the U.S. Geological Survey National Water Quality LaboratoryDetermination of wastewater compounds by polystyrenedivinylbenzene solid-phase extraction and capillary-column gas chromatography/mass spectrometry: U.S. Geological Survey Water-Resources Investigations Report 01-4186, $37 \mathrm{p}$.

Zaugg, S.D., Sandstrom, M.W., Smith, S.G., and Fehlberg, K.M., 1995, Methods of analysis by the U.S. Geological Survey National Water Quality Laboratory-Determination of pesticides in water by $\mathrm{C}-18$ solid-phase extraction and capillary-column gas chromatography/mass spectrometry with selected-ion monitoring: U.S. Geological Survey Open-File Report 95-181, 60 p.

Zogorski, J.S., Carter, J.M., Ivahnenko, Tamara, Lapham, W.W., Moran, M.J., Rowe, B.L., Squillace, P.J., and Toccalino, P.L., 2006, The quality of our Nation's watersVolatile organic compounds in the Nation's ground water and drinking-water supply wells: U.S. Geological Survey Circular 1292, $101 \mathrm{p}$. 



\section{Glossary}

B

Benchmark Quotient (BO) Ratio of the concentration of a contaminant to its Maximum Contaminant Level (MCL) value for a regulated compound or to its Health Based-Screening Level (HBSL) value for an unregulated compound. BQs greater than 1.0 identify concentrations of potential concern. $\mathrm{BQs}$ greater than 0.1 identify compounds that may warrant inclusion in a low-concentration, trends-monitoring program.

B0max Ratio of the maximum concentration of a contaminant to its MCL or HBSL value.

Blended Water As used in this report, finished water that has been blended with one or more different ground-water sources. Finished water blended with surface water was not sampled as part of this study.

C

Concentration of Potential Human-Health Concern As used in this report: (1) for a regulated compound with a U.S. Environmental Protection Agency (USEPA) drinking-water standard, a concentration greater than the Maximum Contaminant Level; and (2) for an unregulated compound, a concentration greater than the Health-Based Screening Level.

Community Water System (CWS) A public water system with 15 or more connections and serving 25 or more year-round residents and thus is subject to USEPA regulations enforcing the Safe Drinking Water Act. A CWS serves a residential population, such as a municipality, mobile home park, or nursing home.

\section{D}

Drinking-Water Guideline As used in this report, a threshold concentration that has no regulatory status, but is issued in an advisory capacity by the USEPA or State agencies.

Drinking-Water Standard As used in this report, a threshold concentration that is legally enforceable (such as MCLs) by the USEPA or State agencies.

$\mathbf{F}$

Finished Water Water is "finished" when it has passed through all the processes in a water treatment plant and is ready to be delivered to consumers.

\section{H}

Health-Based Screening Level (HBSL) An estimate of a benchmark concentration (for a noncarcinogen) or concentration range (for a carcinogen) in water that (1) may be of potential human-health concern; (2) can be used as a threshold value against which measured concentrations of contaminants in water samples can be compared; and (3) is consistent with USEPA Office of Water methodologies.

Human-Health Benchmarks As used in this report, these include USEPA MCL values and HBSL values developed collaboratively by the U.S. Geological Survey, USEPA, New Jersey Department of Environmental Protection, and Oregon Health \& Science University.

\section{M}

Maximum Contaminant Level (MCL) As used in this report, a USEPA drinking-water standard that is legally enforceable, and that sets the maximum permissible level of a contaminant in water that is delivered to any user of a public water system at which no known or anticipated adverse effect on the health of persons occurs and which allows an adequate margin of safety.

\section{R}

Regulated Compound As used in this report, a compound for which a Federal drinking-water standard has been established.

\section{S}

Source Water The raw (ambient) water collected at the supply well or surface-water intake prior to any treatment used to produce finished water.

U

Unregulated Compound As used in this report, a compound for which no Federal drinking-water standard has been established. Note that a compound that is unregulated under the Safe Drinking Water Act may be regulated in other contexts and under other statutes. 

Appendix 1. Concentration and Benchmark Quotient Values for Detected Anthropogenic Organic Compounds in Samples of Source Water and Associated Finished Water, Connecticut SWQA Study 
Appendix 1. Concentration and benchmark quotient values for detected anthropogenic organic compounds in samples of source water and associated finished water, Connecticut SWOA study.

[E, estimated value; $\mu \mathrm{g} / \mathrm{L}$, micrograms per liter; <, less than; red type indicates blended water]

\begin{tabular}{lll} 
E & .083 & $\begin{array}{l}\text { Estimated value } \\
\text { Not analyzed } \\
\text { Blended source }\end{array}$ \\
\hline$<$ & 0.5 & $\begin{array}{l}\text { Detected value above the reporting limit } \\
\text { BQ value at or above } 0.1\end{array}$ \\
& 0.1 & BQ value at or above 1 \\
\hline & 2 & BQ value a
\end{tabular}

\begin{tabular}{|c|c|c|c|c|c|c|}
\hline \multirow{2}{*}{$\begin{array}{c}\text { Well } \\
\text { number } \\
\text { (see } \\
\text { fig. 2) }\end{array}$} & \multirow[b]{2}{*}{$\begin{array}{l}\text { Sample date } \\
\text { and time }\end{array}$} & \multirow[b]{2}{*}{ Regulated (R) or unregulated (U) compound } & \multicolumn{2}{|c|}{ Source water } & \multicolumn{2}{|c|}{ Finished water } \\
\hline & & & $\begin{array}{c}\text { Concentra- } \\
\text { tion } \\
(\mu \mathrm{g} / \mathrm{L})\end{array}$ & $\begin{array}{c}\text { Benchmark } \\
\text { quotient }\end{array}$ & $\begin{array}{c}\text { Concentra- } \\
\text { tion } \\
(\mu \mathrm{g} / \mathrm{L})\end{array}$ & $\begin{array}{c}\text { Benchmark } \\
\text { quotient }\end{array}$ \\
\hline
\end{tabular}

\begin{tabular}{|c|c|c|}
\hline 3 & 6/18/04 10:15 AM & 1,1,1-Trichloroethane $(\mathrm{R})$ \\
\hline 4 & 7/15/04 11:15 AM & $1,1,1$-Trichloroethane $(\mathrm{R})$ \\
\hline 5 & 7/30/04 11:40 AM & 1,1,1-Trichloroethane $(\mathrm{R})$ \\
\hline 7 & 7/23/04 10:00 AM & $1,1,1$-Trichloroethane $(\mathrm{R})$ \\
\hline 8 & 7/14/04 10:00 AM & $1,1,1$-Trichloroethane $(\mathrm{R})$ \\
\hline 9 & 6/23/04 10:30 AM & 1,1,1-Trichloroethane $(\mathrm{R})$ \\
\hline 10 & 6/17/04 10:45 AM & $1,1,1$-Trichloroethane $(\mathrm{R})$ \\
\hline 11 & 6/22/04 10:30 AM & $1,1,1$-Trichloroethane $(\mathrm{R})$ \\
\hline 12 & 6/22/04 1:30 PM & 1,1,1-Trichloroethane $(\mathrm{R})$ \\
\hline 14 & 6/29/04 10:40 AM & 1,1,1-Trichloroethane $(\mathrm{R})$ \\
\hline
\end{tabular}

Volatile organic compounds

\begin{tabular}{|c|c|c|}
\hline 3 & 6/18/04 10:15 AM & 1,1,2-Trichloro-1,2,2- $\operatorname{Tr}$ \\
\hline 4 & 7/15/04 11:15 AM & 1,1,2-Trichloro-1,2,2- $\operatorname{Tr}$ \\
\hline 5 & 7/30/04 11:40 AM & 1,1,2-Trichloro-1,2,2-1 \\
\hline 7 & 7/23/04 10:00 AM & 1,1,2-Trichloro-1,2, \\
\hline 8 & 7/14/04 10:00 AM & 1,1,2-Trichloro-1,2, \\
\hline 9 & 6/23/04 10:30 AM & 1,1,2-Trichloro-1,2,2-T \\
\hline 10 & 6/17/04 10:45 AM & $1,1,2$-Trichloro-1,2,2 \\
\hline 11 & 6/22/04 10:30 AM & 1,1,2-Trichloro-1,2, \\
\hline 12 & 6/22/04 1:30 PM & 1,1,2-Trichloro-1,2,2 \\
\hline 14 & 6/29/04 10:40 AM & 1,1,2-Trichloro-1,2, \\
\hline 3 & 6/18/04 10:15 AM & 1,1-Dichloroethane (U) \\
\hline 4 & 7/15/04 11:15 AM & 1,1-Dichloroethane (U) \\
\hline 5 & 7/30/04 11:40 AM & 1,1-Dichloroethane (U) \\
\hline 7 & 7/23/04 10:00 AM & 1,1-Dichloroethane (U) \\
\hline 8 & 7/14/04 10:00 AM & 1,1-Dichloroethane (U) \\
\hline 9 & 6/23/04 10:30 AM & 1,1-Dichloroethane (U) \\
\hline 10 & 6/17/04 10:45 AM & 1,1-Dichloroethane (U) \\
\hline 11 & 6/22/04 10:30 AM & 1,1-Dichloroethane (U) \\
\hline 12 & 6/22/04 1:30 PM & 1,1-Dichloroethane (U) \\
\hline 14 & 6/29/04 10:40 AM & 1,1-Dichloroethane (U \\
\hline
\end{tabular}

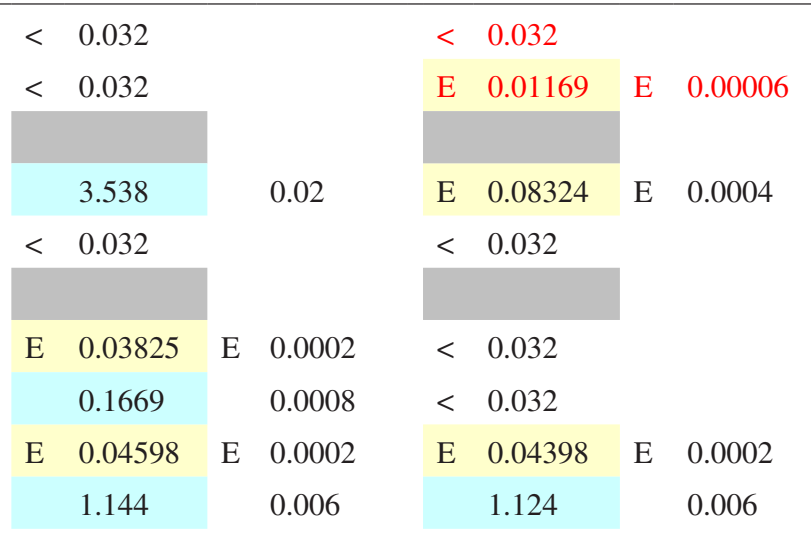

$<0.038$

$<0.038$

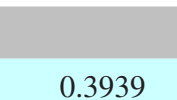

$<0.038$

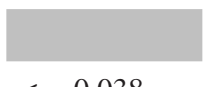

$<0.038$

$<0.038$

$<0.038$

$<0.038$

$<0.035$

$<0.035$

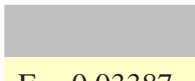

0.000002

$<0.038$

$<0.038$

$<0.038$

$<0.038$

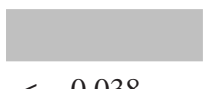

$<0.038$

$<0.038$

$<0.038$

$<0.038$
E 0.03387

$<0.035$

$$
\begin{array}{ll}
< & 0.035 \\
\text { E } & 0.06816 \\
< & 0.035 \\
& 0.1396
\end{array}
$$

$<0.035$

$<0.035$

$$
\begin{aligned}
& <0.035 \\
& <0.035
\end{aligned}
$$

$<0.035$
$<0.035$
$<0.035$


Appendix 1. Concentration and benchmark quotient values for detected anthropogenic organic compounds in samples of source water and associated finished water, Connecticut SWQA study.-Continued

[E, estimated value; $\mu \mathrm{g} / \mathrm{L}$, micrograms per liter; <, less than; red type indicates blended water]

\begin{tabular}{ll|l} 
E & .083 & $\begin{array}{l}\text { Estimated value } \\
\text { Not analyzed } \\
\text { Blended source }\end{array}$ \\
\hline$<$ & 0.5 & Detected value above the reporting limit \\
& 0.0071 & BQ value at or above 0.1 \\
0.1 & BQ value at or above 1 \\
\hline & 2 &
\end{tabular}

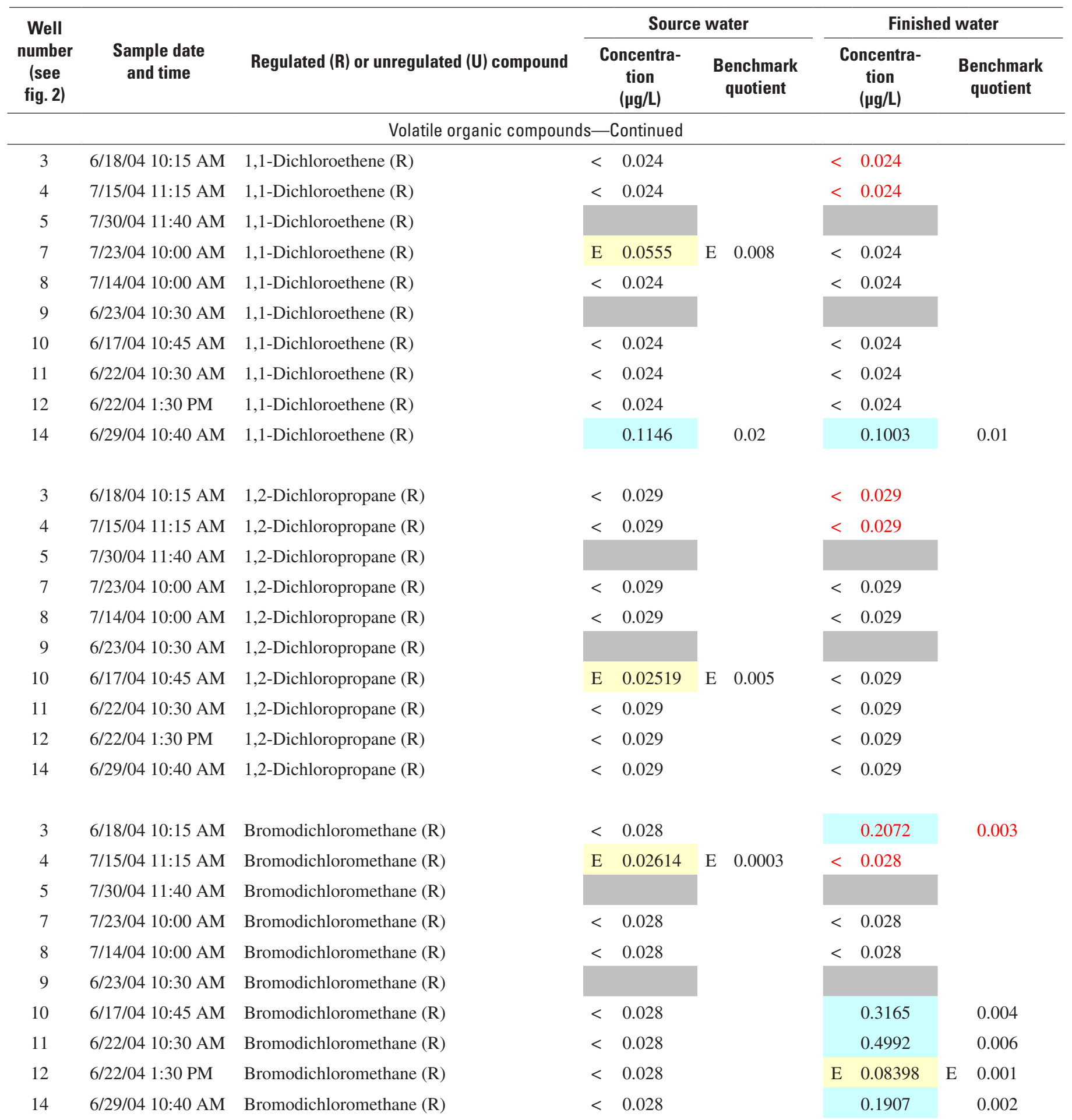


Appendix 1. Concentration and benchmark quotient values for detected anthropogenic organic compounds in samples of source water and associated finished water, Connecticut SWOA study.-Continued

[E, estimated value; $\mu \mathrm{g} / \mathrm{L}$, micrograms per liter; <, less than; red type indicates blended water]

\begin{tabular}{lll} 
E & .083 & $\begin{array}{l}\text { Estimated value } \\
\text { Not analyzed } \\
\text { Blended source }\end{array}$ \\
\hline$<$ & 0.5 & $\begin{array}{l}\text { Detected value above the reporting limit } \\
0.0071\end{array}$ \\
0.1 & BQ value at or above 0.1 \\
\hline & BQ value at or above 1
\end{tabular}

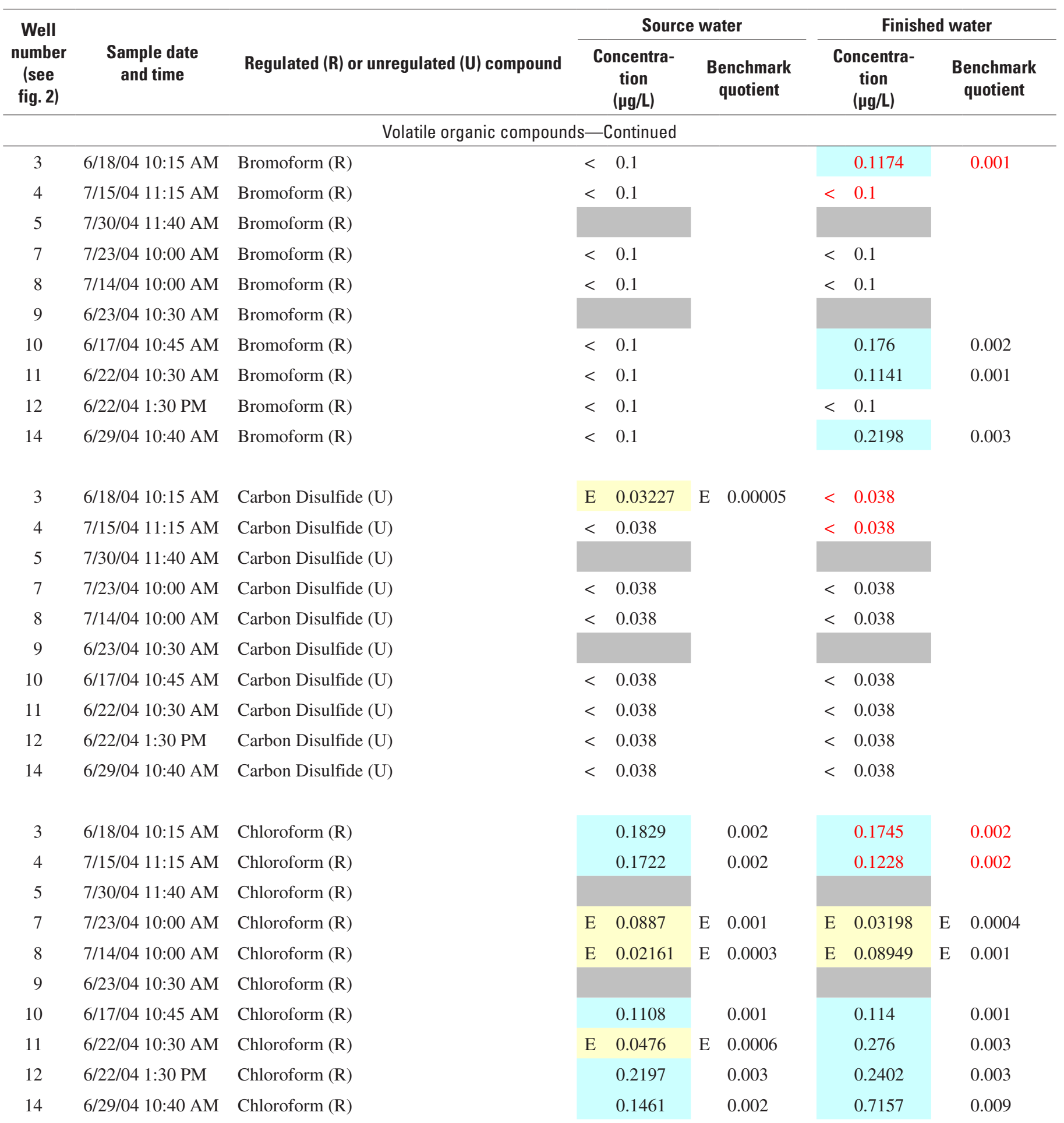


Appendix 1. Concentration and benchmark quotient values for detected anthropogenic organic compounds in samples of source water and associated finished water, Connecticut SWQA study.-Continued

[E, estimated value; $\mu \mathrm{g} / \mathrm{L}$, micrograms per liter; <, less than; red type indicates blended water]

\begin{tabular}{lll} 
E & .083 & $\begin{array}{l}\text { Estimated value } \\
\text { Not analyzed }\end{array}$ \\
\hline$<$ & 0.5 & $\begin{array}{l}\text { Blended source } \\
\text { Detected value above the reporting limit } \\
\\
\end{array}$ \\
& 0.0071 & BQ value at or above 0.1 \\
2 & BQ value at or above 1
\end{tabular}

\begin{tabular}{|c|c|c|c|c|c|c|c|c|c|}
\hline \multirow{2}{*}{$\begin{array}{c}\text { Well } \\
\text { number } \\
\text { (see } \\
\text { fig. 2) }\end{array}$} & \multirow[b]{2}{*}{$\begin{array}{l}\text { Sample date } \\
\text { and time }\end{array}$} & \multirow[b]{2}{*}{ Regulated (R) or unregulated (U) compound } & \multicolumn{3}{|c|}{ Source water } & \multicolumn{4}{|c|}{ Finished water } \\
\hline & & & \multicolumn{2}{|c|}{$\begin{array}{c}\text { Concentra- } \\
\text { tion } \\
(\mu \mathrm{g} / \mathrm{L})\end{array}$} & $\begin{array}{c}\text { Benchmark } \\
\text { quotient }\end{array}$ & \multicolumn{2}{|c|}{$\begin{array}{c}\text { Concentra- } \\
\text { tion } \\
(\mu \mathrm{g} / \mathrm{L})\end{array}$} & \multicolumn{2}{|c|}{$\begin{array}{c}\text { Benchmark } \\
\text { quotient }\end{array}$} \\
\hline \multicolumn{10}{|c|}{ Volatile organic compounds-Continued } \\
\hline 3 & 6/18/04 10:15 AM & cis-1,2-Dichloroethene (R) & $<$ & 0.024 & & $<$ & 0.024 & & \\
\hline 4 & 7/15/04 11:15 AM & cis-1,2-Dichloroethene (R) & $<$ & 0.024 & & $<$ & 0.024 & & \\
\hline 5 & 7/30/04 11:40 AM & cis-1,2-Dichloroethene (R) & & & & & & & \\
\hline 7 & 7/23/04 10:00 AM & cis-1,2-Dichloroethene (R) & & 0.1585 & 0.002 & $\mathrm{E}$ & 0.03547 & $\mathrm{E}$ & 0.0005 \\
\hline 8 & 7/14/04 10:00 AM & cis-1,2-Dichloroethene (R) & $<$ & 0.024 & & $<$ & 0.024 & & \\
\hline 9 & 6/23/04 10:30 AM & cis-1,2-Dichloroethene (R) & & & & & & & \\
\hline 10 & 6/17/04 10:45 AM & cis-1,2-Dichloroethene (R) & $<$ & 0.024 & & $<$ & 0.024 & & \\
\hline 11 & 6/22/04 10:30 AM & cis-1,2-Dichloroethene (R) & & 0.131 & 0.002 & $<$ & 0.024 & & \\
\hline 12 & $6 / 22 / 04$ 1:30 PM & cis-1,2-Dichloroethene (R) & $<$ & 0.024 & & $<$ & 0.024 & & \\
\hline 14 & 6/29/04 10:40 AM & cis-1,2-Dichloroethene (R) & $\mathrm{E}$ & 0.03209 & E $\quad 0.0005$ & $\mathrm{E}$ & 0.02977 & $\mathrm{E}$ & 0.0004 \\
\hline 3 & 6/18/04 10:15 AM & Dibromochloromethane (R) & $<$ & 0.1 & & & 0.3691 & & 0.005 \\
\hline 4 & 7/15/04 11:15 AM & Dibromochloromethane (R) & $<$ & 0.1 & & $<$ & 0.1 & & \\
\hline 5 & 7/30/04 11:40 AM & Dibromochloromethane (R) & & & & & & & \\
\hline 7 & 7/23/04 10:00 AM & Dibromochloromethane (R) & $<$ & 0.1 & & $<$ & 0.1 & & \\
\hline 8 & 7/14/04 10:00 AM & Dibromochloromethane (R) & $<$ & 0.1 & & $<$ & 0.1 & & \\
\hline 9 & 6/23/04 10:30 AM & Dibromochloromethane (R) & & & & & & & \\
\hline 10 & 6/17/04 10:45 AM & Dibromochloromethane (R) & $<$ & 0.1 & & & 0.4472 & & 0.006 \\
\hline 11 & 6/22/04 10:30 AM & Dibromochloromethane (R) & $<$ & 0.1 & & & 0.5078 & & 0.006 \\
\hline 12 & 6/22/04 1:30 PM & Dibromochloromethane (R) & $<$ & 0.1 & & & 0.104 & & 0.001 \\
\hline 14 & 6/29/04 10:40 AM & Dibromochloromethane (R) & $<$ & 0.1 & & & 0.4065 & & 0.005 \\
\hline 3 & 6/18/04 10:15 AM & Ethyl tert-butyl ether (ETBE) (U) & $<$ & 0.05 & & $<$ & 0.05 & & \\
\hline 4 & 7/15/04 11:15 AM & Ethyl tert-butyl ether (ETBE) (U) & $<$ & 0.05 & & $<$ & 0.05 & & \\
\hline 5 & 7/30/04 11:40 AM & Ethyl tert-butyl ether (ETBE) (U) & & & & & & & \\
\hline 7 & 7/23/04 10:00 AM & Ethyl tert-butyl ether (ETBE) (U) & & 0.2409 & & & 0.1452 & & \\
\hline 8 & 7/14/04 10:00 AM & Ethyl tert-butyl ether (ETBE) (U) & $<$ & 0.05 & & $<$ & 0.05 & & \\
\hline 9 & 6/23/04 10:30 AM & Ethyl tert-butyl ether (ETBE) (U) & & & & & & & \\
\hline 10 & 6/17/04 10:45 AM & Ethyl tert-butyl ether (ETBE) (U) & $<$ & 0.05 & & $<$ & 0.05 & & \\
\hline 11 & 6/22/04 10:30 AM & Ethyl tert-butyl ether (ETBE) (U) & $<$ & 0.05 & & $<$ & 0.05 & & \\
\hline 12 & 6/22/04 1:30 PM & Ethyl tert-butyl ether (ETBE) (U) & $<$ & 0.05 & & $<$ & 0.05 & & \\
\hline 14 & 6/29/04 10:40 AM & Ethyl tert-butyl ether (ETBE) (U) & $<$ & 0.05 & & $<$ & 0.05 & & \\
\hline
\end{tabular}


Appendix 1. Concentration and benchmark quotient values for detected anthropogenic organic compounds in samples of source water and associated finished water, Connecticut SWOA study.-Continued

[E, estimated value; $\mu \mathrm{g} / \mathrm{L}$, micrograms per liter; <, less than; red type indicates blended water]

\begin{tabular}{lll} 
E & .083 & $\begin{array}{l}\text { Estimated value } \\
\text { Not analyzed }\end{array}$ \\
\hline$<$ & 0.5 & Blended source \\
& 0.0071 & Detected value above the reporting limit \\
0.1 & BQ value at or above 0.1 \\
\hline & BQ value at or above 1
\end{tabular}

\begin{tabular}{|c|c|c|c|c|c|c|c|c|}
\hline \multirow{2}{*}{$\begin{array}{c}\text { Well } \\
\text { number } \\
\text { (see } \\
\text { fig. 2) }\end{array}$} & \multirow[b]{2}{*}{$\begin{array}{l}\text { Sample date } \\
\text { and time }\end{array}$} & \multirow[b]{2}{*}{ Regulated (R) or unregulated (U) compound } & \multicolumn{3}{|c|}{ Source water } & \multicolumn{3}{|c|}{ Finished water } \\
\hline & & & & $\begin{array}{l}\text { Poncentra- } \\
\text { tion } \\
(\mu \mathrm{g} / \mathrm{L})\end{array}$ & $\begin{array}{c}\text { Benchmark } \\
\text { quotient }\end{array}$ & & $\begin{array}{l}\text { Soncentra- } \\
\text { tion } \\
(\mu \mathrm{g} / \mathrm{L})\end{array}$ & $\begin{array}{c}\text { Benchmark } \\
\text { quotient }\end{array}$ \\
\hline \multicolumn{9}{|c|}{ Volatile organic compounds-Continued } \\
\hline 3 & 6/18/04 10:15 AM & $m$ - \& p-xylene (U) & $<$ & 0.06 & & $<$ & 0.06 & \\
\hline 7 & 7/23/04 10:00 AM & $m$ - \& p-xylene (U) & $<$ & 0.06 & & $<$ & 0.06 & \\
\hline 8 & 7/14/04 10:00 AM & $m$ - \& p-xylene $(\mathrm{U})$ & $<$ & 0.06 & & $<$ & 0.06 & \\
\hline 9 & 6/23/04 10:30 AM & $m$ - \& p-xylene (U) & & & & & & \\
\hline 10 & 6/17/04 10:45 AM & $m$ - \& p-xylene (U) & $<$ & 0.06 & & $\mathrm{E}$ & 0.02209 & 0.000002 \\
\hline 14 & 6/29/04 10:40 AM & $m$ - \& p-xylene (U) & $<$ & 0.06 & & $<$ & 0.06 & \\
\hline 3 & 6/18/04 10:15 AM & Methyl tert-butyl ether (MTBE) (U) & $<$ & 0.17 & & $<$ & 0.17 & \\
\hline 4 & 7/15/04 11:15 AM & Methyl tert-butyl ether (MTBE) (U) & & 0.7355 & & $<$ & 0.17 & \\
\hline 5 & 7/30/04 11:40 AM & Methyl tert-butyl ether (MTBE) (U) & & & & & & \\
\hline 7 & 7/23/04 10:00 AM & Methyl tert-butyl ether (MTBE) (U) & & 7.843 & & & 6.033 & \\
\hline 8 & 7/14/04 10:00 AM & Methyl tert-butyl ether (MTBE) (U) & $<$ & 0.17 & & $<$ & 0.17 & \\
\hline 9 & 6/23/04 10:30 AM & Methyl tert-butyl ether (MTBE) (U) & & & & & & \\
\hline 10 & 6/17/04 10:45 AM & Methyl tert-butyl ether (MTBE) (U) & $<$ & 0.17 & & $<$ & 0.17 & \\
\hline 4 & 7/15/04 11:15 AM & tert-Amyl methyl ether (TAME) (U) & $<$ & 0.08 & & $<$ & 0.08 & \\
\hline 5 & 7/30/04 11:40 AM & tert-Amyl methyl ether (TAME) (U) & & & & & & \\
\hline 7 & 7/23/04 10:00 AM & tert-Amyl methyl ether (TAME) (U) & & 0.935 & & & 0.6555 & \\
\hline 8 & 7/14/04 10:00 AM & tert-Amyl methyl ether (TAME) (U) & $<$ & 0.08 & & $<$ & 0.08 & \\
\hline 9 & 6/23/04 10:30 AM & tert-Amyl methyl ether (TAME) (U) & & & & & & \\
\hline 10 & 6/17/04 10:45 AM & tert-Amyl methyl ether (TAME) (U) & $<$ & 0.08 & & $<$ & 0.08 & \\
\hline 11 & 6/22/04 10:30 AM & tert-Amyl methyl ether (TAME) (U) & $<$ & 0.08 & & $<$ & 0.08 & \\
\hline 12 & 6/22/04 1:30 PM & tert-Amyl methyl ether (TAME) (U) & $<$ & 0.08 & & $<$ & 0.08 & \\
\hline 14 & 6/29/04 10:40 AM & tert-Amyl methyl ether (TAME) (U) & $<$ & 0.08 & & $<$ & 0.08 & \\
\hline
\end{tabular}


Appendix 1. Concentration and benchmark quotient values for detected anthropogenic organic compounds in samples of source water and associated finished water, Connecticut SWQA study.-Continued

[E, estimated value; $\mu \mathrm{g} / \mathrm{L}$, micrograms per liter; <, less than; red type indicates blended water]

\begin{tabular}{lll} 
E & .083 & $\begin{array}{l}\text { Estimated value } \\
\text { Not analyzed } \\
\text { Blended source }\end{array}$ \\
\hline$<$ & 0.5 & $\begin{array}{l}\text { Detected value above the reporting limit } \\
0.0071\end{array}$ \\
0.1 & BQ value at or above 0.1 \\
2 & BQ value at or above 1
\end{tabular}

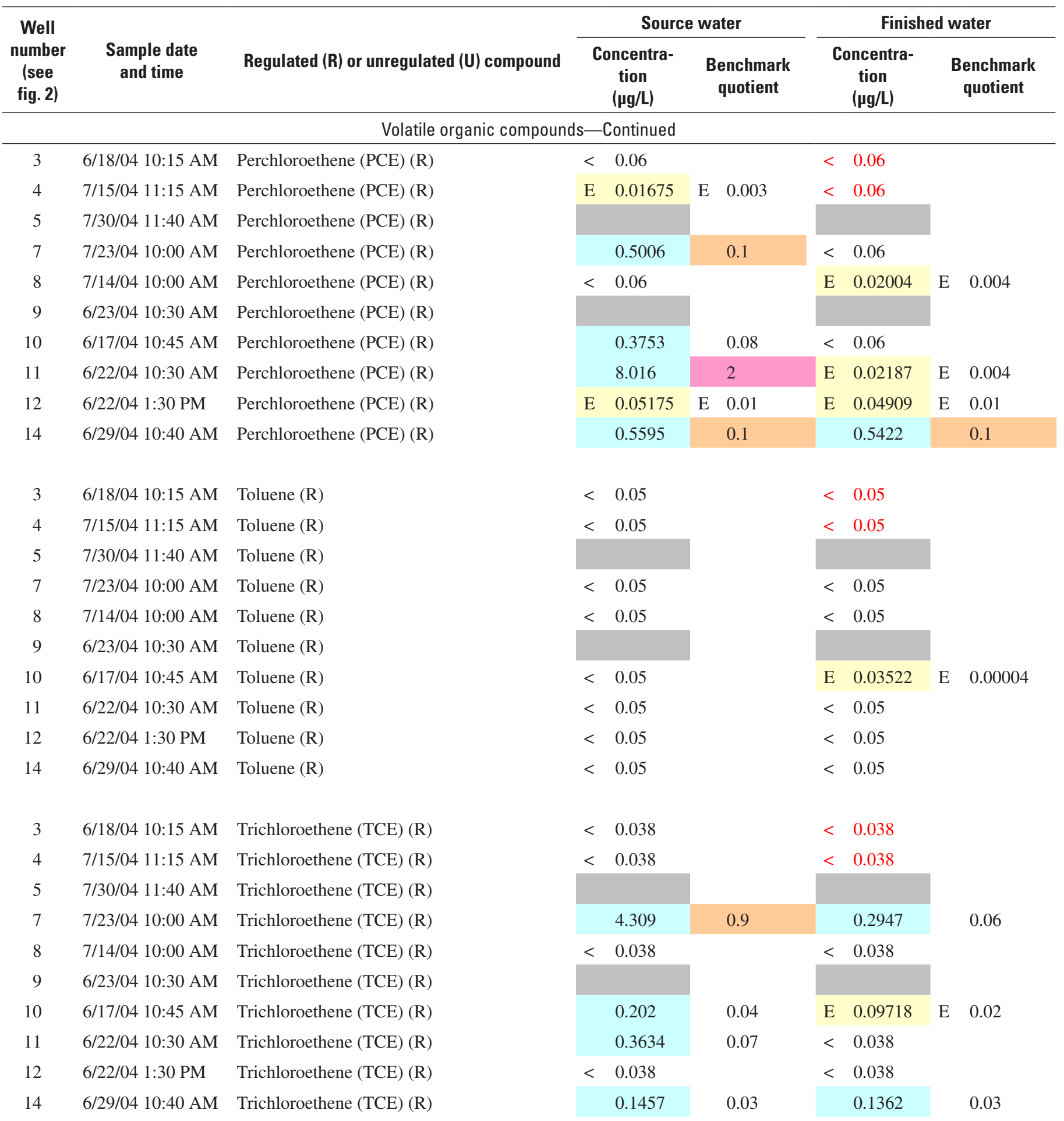


Appendix 1. Concentration and benchmark quotient values for detected anthropogenic organic compounds in samples of source water and associated finished water, Connecticut SWOA study.-Continued

[E, estimated value; $\mu \mathrm{g} / \mathrm{L}$, micrograms per liter; <, less than; red type indicates blended water]

\begin{tabular}{lll} 
E & .083 & $\begin{array}{l}\text { Estimated value } \\
\text { Not analyzed }\end{array}$ \\
\hline$<$ & 0.5 & Blended source \\
& 0.0071 & Detected value above the reporting limit \\
0.1 & BQ value at or above 0.1 \\
\hline & BQ value at or above 1
\end{tabular}

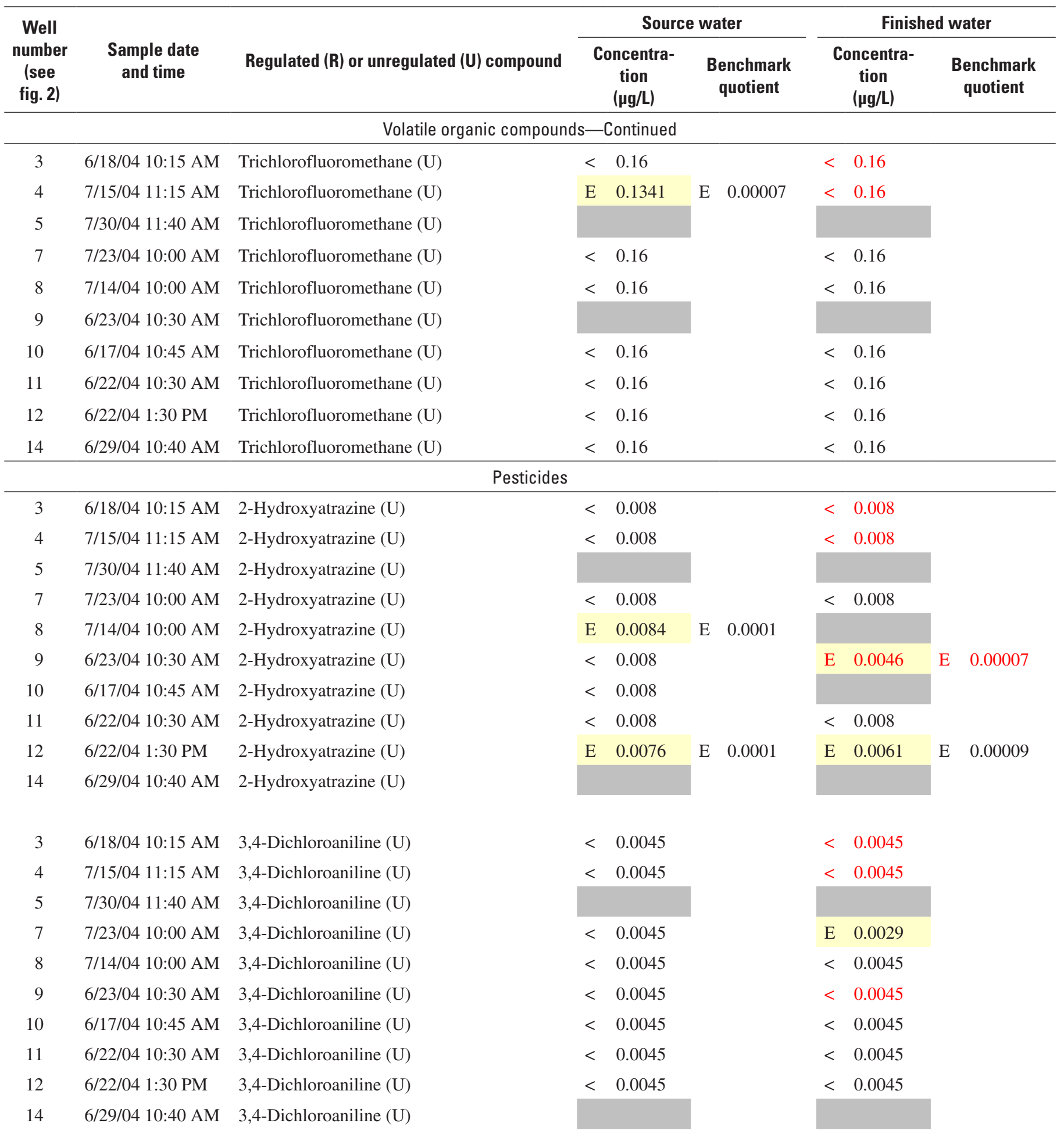


Appendix 1. Concentration and benchmark quotient values for detected anthropogenic organic compounds in samples of source water and associated finished water, Connecticut SWQA study.-Continued

[E, estimated value; $\mu \mathrm{g} / \mathrm{L}$, micrograms per liter; <, less than; red type indicates blended water]

\begin{tabular}{lll} 
E & .083 & $\begin{array}{l}\text { Estimated value } \\
\text { Not analyzed }\end{array}$ \\
\hline$<$ & 0.5 & $\begin{array}{l}\text { Blended source } \\
\text { Detected value above the reporting limit } \\
\\
\end{array}$ \\
& 0.0071 & BQ value at or above 0.1 \\
2 & BQ value at or above 1
\end{tabular}

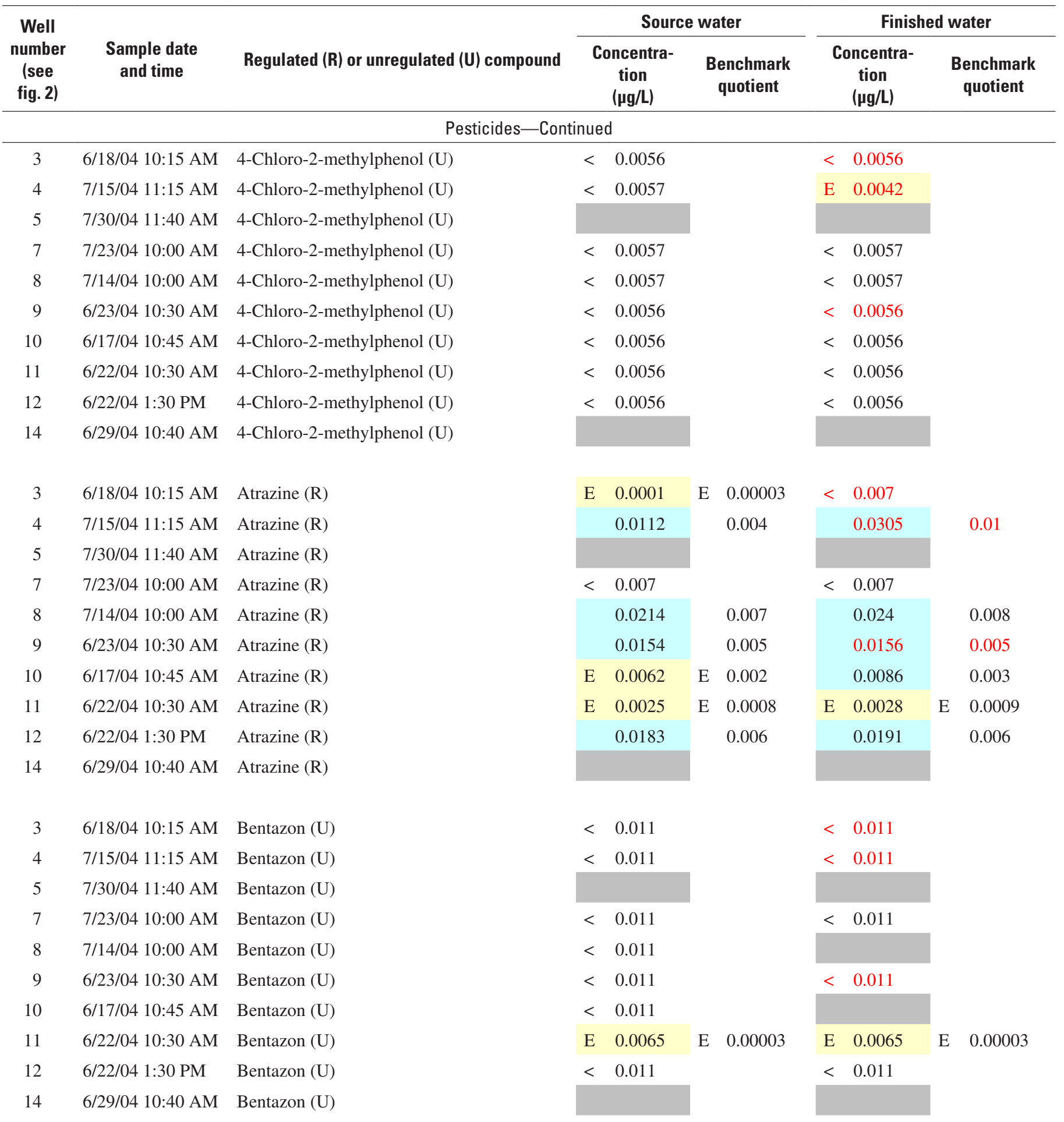


Appendix 1. Concentration and benchmark quotient values for detected anthropogenic organic compounds in samples of source water and associated finished water, Connecticut SWOA study.-Continued

[E, estimated value; $\mu \mathrm{g} / \mathrm{L}$, micrograms per liter; <, less than; red type indicates blended water]

\begin{tabular}{lll} 
E & .083 & $\begin{array}{l}\text { Estimated value } \\
\text { Not analyzed } \\
\text { Blended source }\end{array}$ \\
\hline$<$ & 0.5 & $\begin{array}{l}\text { Detected value above the reporting limit } \\
0.0071\end{array}$ \\
0.1 & BQ value at or above 0.1 \\
\hline & BQ value at or above 1
\end{tabular}

\begin{tabular}{|c|c|c|c|c|c|c|c|c|}
\hline \multirow{2}{*}{$\begin{array}{c}\text { Well } \\
\text { number } \\
\text { (see } \\
\text { fig. 2) }\end{array}$} & \multirow[b]{2}{*}{$\begin{array}{l}\text { Sample date } \\
\text { and time }\end{array}$} & \multirow[b]{2}{*}{ Regulated (R) or unregulated (U) compound } & \multicolumn{3}{|c|}{ Source water } & \multicolumn{3}{|c|}{ Finished water } \\
\hline & & & \multicolumn{2}{|c|}{$\begin{array}{c}\text { Concentra- } \\
\text { tion } \\
(\mu \mathrm{g} / \mathrm{L})\end{array}$} & \multirow[t]{2}{*}{$\begin{array}{l}\text { Benchmark } \\
\text { quotient }\end{array}$} & \multirow{2}{*}{\multicolumn{2}{|c|}{$\begin{array}{c}\text { Concentra- } \\
\text { tion } \\
(\mu \mathrm{g} / \mathrm{L})\end{array}$}} & \multirow[t]{2}{*}{$\begin{array}{c}\text { Benchmark } \\
\text { quotient }\end{array}$} \\
\hline \multicolumn{5}{|c|}{ Pesticides-Continued } & & & & \\
\hline 3 & 6/18/04 10:15 AM & Deethylatrazine (U) & $\mathrm{E}$ & 0.0021 & & $\mathrm{E}$ & 0.0022 & \\
\hline 7 & 7/23/04 10:00 AM & Deethylatrazine (U) & $<$ & 0.006 & & $<$ & 0.006 & \\
\hline 8 & 7/14/04 10:00 AM & Deethylatrazine (U) & $\mathrm{E}$ & 0.0159 & & $\mathrm{E}$ & 0.0186 & \\
\hline 9 & 6/23/04 10:30 AM & Deethylatrazine (U) & $\mathrm{E}$ & 0.0097 & & $\mathrm{E}$ & 0.0088 & \\
\hline 10 & 6/17/04 10:45 AM & Deethylatrazine (U) & $\mathrm{E}$ & 0.006 & & $\mathrm{E}$ & 0.0077 & \\
\hline 3 & 6/18/04 10:15 AM & Diazinon (U) & $<$ & 0.005 & & $<$ & 0.005 & \\
\hline 4 & 7/15/04 11:15 AM & Diazinon (U) & & 0.0099 & & & 0.0052 & \\
\hline 5 & 7/30/04 11:40 AM & Diazinon (U) & $<$ & 0.5 & & $<$ & 0.5 & \\
\hline 7 & 7/23/04 10:00 AM & Diazinon (U) & $<$ & 0.005 & & $<$ & 0.005 & \\
\hline 8 & 7/14/04 10:00 AM & Diazinon (U) & $<$ & 0.005 & & $<$ & 0.005 & \\
\hline 9 & 6/23/04 10:30 AM & Diazinon (U) & $<$ & 0.005 & & $<$ & 0.005 & \\
\hline 10 & 6/17/04 10:45 AM & Diazinon (U) & $<$ & 0.005 & & $<$ & 0.005 & \\
\hline 4 & 7/15/04 11:15 AM & Fipronil (U) & $\mathrm{E}$ & 0.0032 & & $<$ & 0.016 & \\
\hline 5 & 7/30/04 11:40 AM & Fipronil (U) & & & & & & \\
\hline 7 & 7/23/04 10:00 AM & Fipronil (U) & $\mathrm{E}$ & 0.0056 & & $<$ & 0.016 & \\
\hline 8 & 7/14/04 10:00 AM & Fipronil (U) & $<$ & 0.016 & & $<$ & 0.016 & \\
\hline 9 & 6/23/04 10:30 AM & Fipronil (U) & $<$ & 0.016 & & $<$ & 0.016 & \\
\hline 10 & 6/17/04 10:45 AM & Fipronil (U) & $<$ & 0.016 & & $<$ & 0.016 & \\
\hline 11 & 6/22/04 10:30 AM & Fipronil (U) & $<$ & 0.016 & & $<$ & 0.016 & \\
\hline 12 & 6/22/04 1:30 PM & Fipronil (U) & $<$ & 0.016 & & $<$ & 0.016 & \\
\hline 14 & 6/29/04 10:40 AM & Fipronil (U) & & & & & & \\
\hline
\end{tabular}


Appendix 1. Concentration and benchmark quotient values for detected anthropogenic organic compounds in samples of source water and associated finished water, Connecticut SWQA study.-Continued

[E, estimated value; $\mu \mathrm{g} / \mathrm{L}$, micrograms per liter; <, less than; red type indicates blended water]

\begin{tabular}{lll} 
E & .083 & $\begin{array}{l}\text { Estimated value } \\
\text { Not analyzed }\end{array}$ \\
\hline$<$ & 0.5 & $\begin{array}{l}\text { Blended source } \\
\text { Detected value above the reporting limit } \\
\\
\end{array}$ \\
& 0.0071 & BQ value at or above 0.1 \\
2 & BQ value at or above 1
\end{tabular}

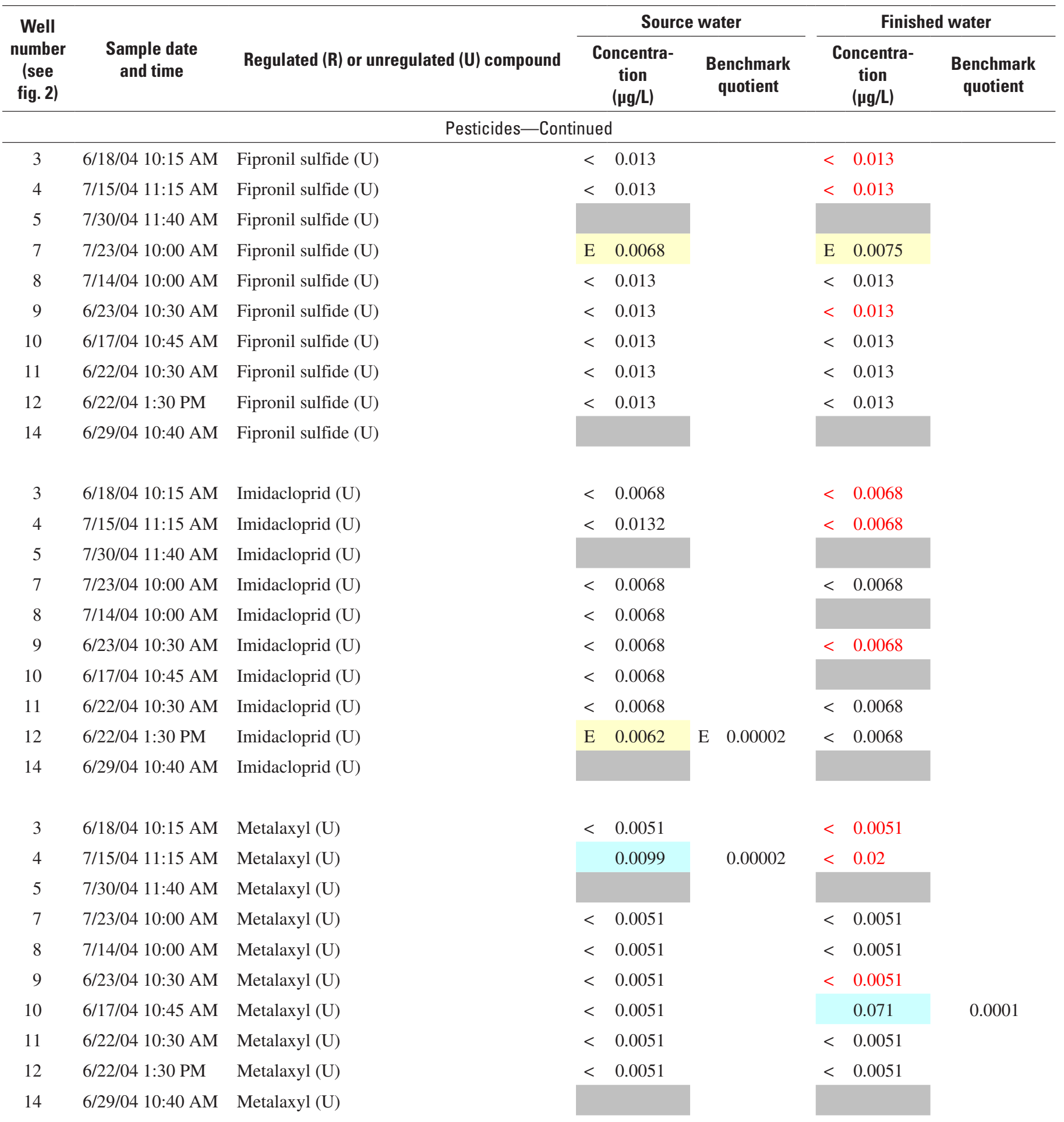


Appendix 1. Concentration and benchmark quotient values for detected anthropogenic organic compounds in samples of source water and associated finished water, Connecticut SWQA study.-Continued

[E, estimated value; $\mu \mathrm{g} / \mathrm{L}$, micrograms per liter; <, less than; red type indicates blended water]

\begin{tabular}{lll} 
E & .083 & $\begin{array}{l}\text { Estimated value } \\
\text { Not analyzed }\end{array}$ \\
\hline$<$ & 0.5 & Blended source \\
& 0.0071 & Detected value above the reporting limit \\
0.1 & BQ value at or above 0.1 \\
\hline & BQ value at or above 1
\end{tabular}

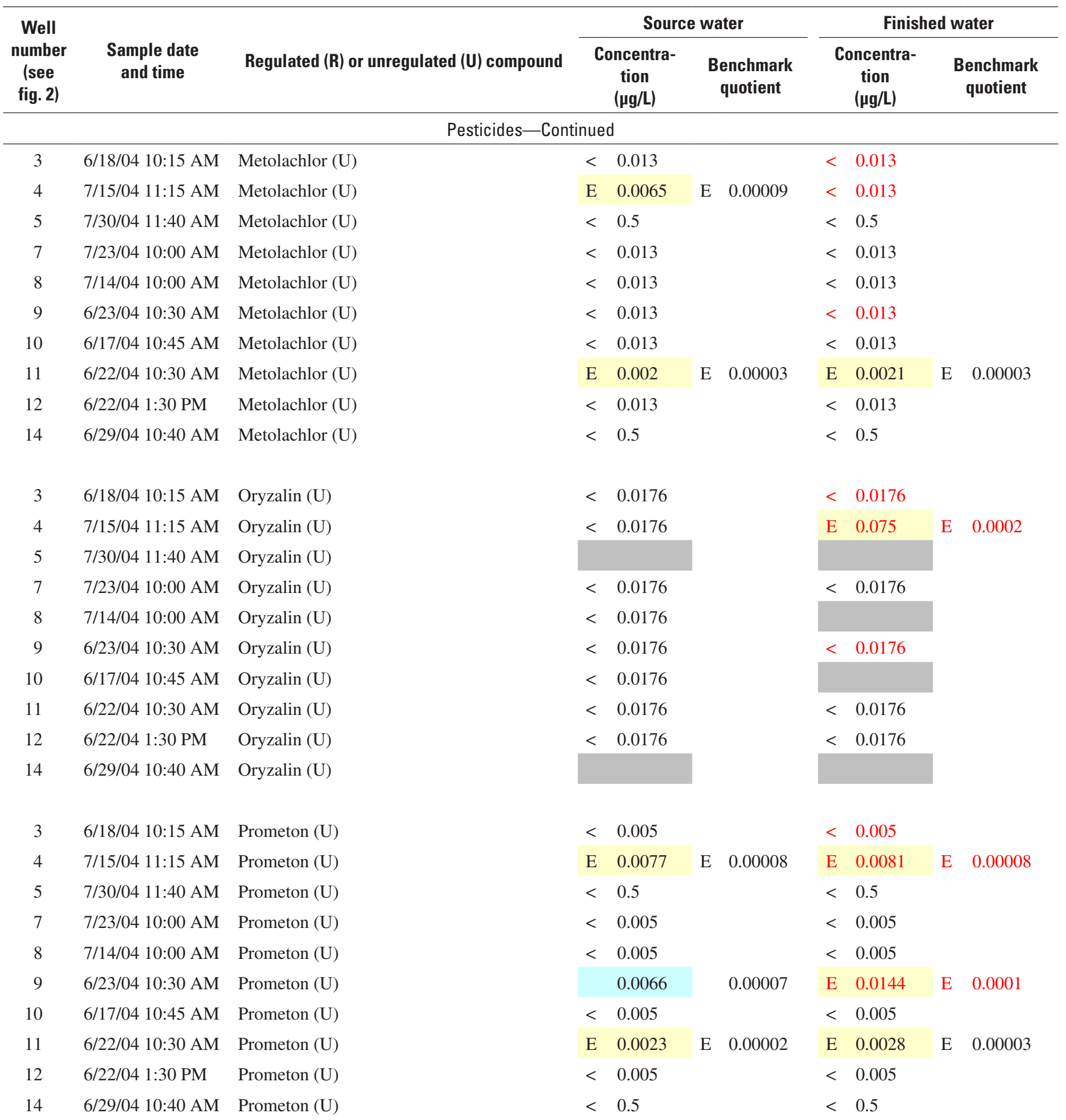


Appendix 1. Concentration and benchmark quotient values for detected anthropogenic organic compounds in samples of source water and associated finished water, Connecticut SWQA study.-Continued

[E, estimated value; $\mu \mathrm{g} / \mathrm{L}$, micrograms per liter; <, less than; red type indicates blended water]

\begin{tabular}{lll} 
E & .083 & $\begin{array}{l}\text { Estimated value } \\
\text { Not analyzed }\end{array}$ \\
$<$ & 0.5 & $\begin{array}{l}\text { Blended source } \\
\text { Detected value above the reporting limit } \\
\end{array}$ \\
& 0.0071 & BQ value at or above 0.1 \\
0.1 & BQ value at or above 1 \\
\hline
\end{tabular}

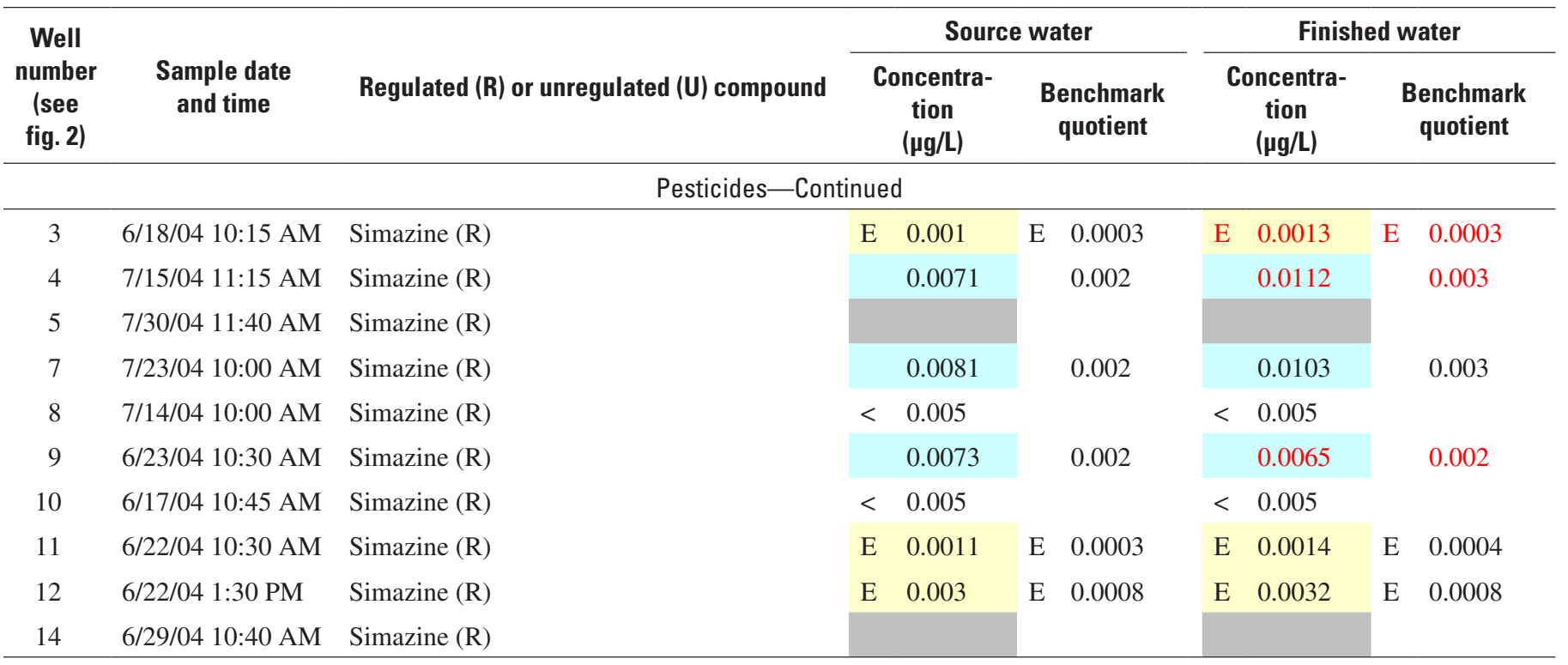

Other anthropogenic organic compounds

$36 / 18 / 04$ 10:15 AM Acetyl hexamethyl tetrahydronaphthalene

$4 \quad 7 / 15 / 0411: 15$ AM Acetyl hexamethyl tetrahydronaphthalene

\section{compounds} (AHTN) (U)

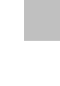

cetyl hexamethyl tetrahydronaphthalene

7/30/04 11:40 AM Acetyl hexame
(AHTN) (U)

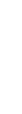

$$
<
$$$$
0.5
$$$$
<0.5
$$

$\begin{array}{ll}<0.5 & <0.5 \\ <0.5 & \text { E } 0.088\end{array}$
(AHTN) (U)

7/14/04 10:00 AM Acetyl hexamethyl tetrahydronaphthalene (AHTN) (U)

$9 \quad 6 / 23 / 04$ 10:30 AM Acetyl hexamethyl tetrahydronaphthalene (AHTN) (U)

$<0.5$

$<0.5$

$<0.5$

$<0.5$

10 6/17/04 10:45 AM Acetyl hexamethyl tetrahydronaphthalene (AHTN) (U)

$<0.5$

$<0.5$

11 6/22/04 10:30 AM Acetyl hexamethyl tetrahydronaphthalene (AHTN) (U)

12 6/22/04 1:30 PM Acetyl hexamethyl tetrahydronaphthalene (AHTN) (U)

14 6/29/04 10:40 AM Acetyl hexamethyl tetrahydronaphthalene (AHTN) (U)
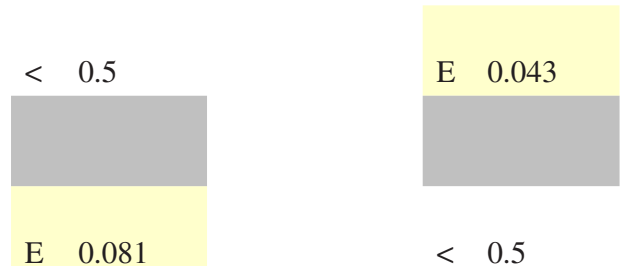

$<0.5$ 
Appendix 1. Concentration and benchmark quotient values for detected anthropogenic organic compounds in samples of source water and associated finished water, Connecticut SWOA study.-Continued

[E, estimated value; $\mu \mathrm{g} / \mathrm{L}$, micrograms per liter; <, less than; red type indicates blended water]

\begin{tabular}{lll} 
E & .083 & $\begin{array}{l}\text { Estimated value } \\
\text { Not analyzed }\end{array}$ \\
\hline$<$ & 0.5 & Blended source \\
& 0.0071 & Detected value above the reporting limit \\
0.1 & BQ value at or above 0.1 \\
\hline & BQ value at or above 1
\end{tabular}

\begin{tabular}{|c|c|c|c|c|c|c|c|c|c|c|}
\hline \multirow{2}{*}{$\begin{array}{c}\text { Well } \\
\text { number } \\
\text { (see } \\
\text { fig. 2) }\end{array}$} & \multirow[b]{2}{*}{$\begin{array}{l}\text { Sample date } \\
\text { and time }\end{array}$} & \multirow[b]{2}{*}{ Regulated (R) or unregulated (U) compound } & \multicolumn{4}{|c|}{ Source water } & \multicolumn{4}{|c|}{ Finished water } \\
\hline & & & \multicolumn{2}{|c|}{$\begin{array}{c}\text { Concentra- } \\
\text { tion } \\
\text { ( } \mu \mathrm{g} / \mathrm{L})\end{array}$} & \multicolumn{2}{|c|}{$\begin{array}{l}\text { Benchmark } \\
\text { quotient }\end{array}$} & \multicolumn{2}{|c|}{$\begin{array}{c}\text { Concentra- } \\
\text { tion } \\
(\mu \mathrm{g} / \mathrm{L})\end{array}$} & \multicolumn{2}{|c|}{$\begin{array}{l}\text { Benchmark } \\
\text { quotient }\end{array}$} \\
\hline \multicolumn{11}{|c|}{ Other anthropogenic organic compounds-Continued } \\
\hline 3 & 6/18/04 10:15 AM & Bisphenol A (U) & & & & & $\mathrm{E}$ & 0.13 & $\mathrm{E}$ & 0.0003 \\
\hline 7 & 7/23/04 10:00 AM & Bisphenol A (U) & $<$ & 1 & & & $<$ & 1 & & \\
\hline 8 & 7/14/04 10:00 AM & Bisphenol A (U) & $\mathrm{E}$ & 0.12 & $\mathrm{E}$ & 0.0003 & $\mathrm{E}$ & 0.11 & $\mathrm{E}$ & 0.0003 \\
\hline 9 & 6/23/04 10:30 AM & Bisphenol A (U) & $<$ & 1 & & & $<$ & 1 & & \\
\hline 10 & 6/17/04 10:45 AM & Bisphenol A (U) & $<$ & 1 & & & $<$ & 1 & & \\
\hline 14 & 6/29/04 10:40 AM & Bisphenol A (U) & & 2.5 & & 0.006 & $<$ & 1 & & \\
\hline 3 & 6/18/04 10:15 AM & $\begin{array}{l}\text { Hexahydrohexamethylcyclopentabenzopyran } \\
\text { (HHCB) (U) }\end{array}$ & & & & & $<$ & 0.5 & & \\
\hline 4 & 7/15/04 11:15 AM & $\begin{array}{l}\text { Hexahydrohexamethylcyclopentabenzopyran } \\
\text { (HHCB) (U) }\end{array}$ & $<$ & 0.5 & & & $<$ & 0.5 & & \\
\hline 5 & 7/30/04 11:40 AM & $\begin{array}{l}\text { Hexahydrohexamethylcyclopentabenzopyran } \\
\text { (HHCB) (U) }\end{array}$ & $<$ & 0.5 & & & $<$ & 0.5 & & \\
\hline 7 & 7/23/04 10:00 AM & $\begin{array}{l}\text { Hexahydrohexamethylcyclopentabenzopyran } \\
\text { (HHCB) (U) }\end{array}$ & $<$ & 0.5 & & & $<$ & 0.5 & & \\
\hline 11 & 6/22/04 10:30 AM & $\begin{array}{l}\text { Hexahydrohexamethylcyclopentabenzopyran } \\
\text { (HHCB) (U) }\end{array}$ & $<$ & 0.5 & & & $<$ & 0.5 & & \\
\hline 12 & 6/22/04 1:30 PM & $\begin{array}{l}\text { Hexahydrohexamethylcyclopentabenzopyran } \\
\text { (HHCB) (U) }\end{array}$ & & & & & & & & \\
\hline 14 & 6/29/04 10:40 AM & $\begin{array}{l}\text { Hexahydrohexamethylcyclopentabenzopyran } \\
\quad(\mathrm{HHCB})(\mathrm{U})\end{array}$ & $\mathrm{E}$ & 0.079 & & & $<$ & 0.5 & & \\
\hline
\end{tabular}


Appendix 1. Concentration and benchmark quotient values for detected anthropogenic organic compounds in samples of source water and associated finished water, Connecticut SWQA study.-Continued

[E, estimated value; $\mu \mathrm{g} / \mathrm{L}$, micrograms per liter; $<$, less than; red type indicates blended water]

\begin{tabular}{ll|l} 
E & .083 & $\begin{array}{l}\text { Estimated value } \\
\text { Not analyzed } \\
\text { Blended source }\end{array}$ \\
\hline$<$ & 0.5 & Detected value above the reporting limit \\
& 0.0071 & BQ value at or above 0.1 \\
0.1 & BQ value at or above 1 \\
\hline & 2 &
\end{tabular}

\begin{tabular}{|c|c|c|c|c|c|c|}
\hline \multirow{2}{*}{$\begin{array}{c}\text { Well } \\
\text { number } \\
\text { (see } \\
\text { fig. 2) }\end{array}$} & \multirow[b]{2}{*}{$\begin{array}{c}\text { Sample date } \\
\text { and time }\end{array}$} & \multirow[b]{2}{*}{ Regulated (R) or unregulated (U) compound } & \multicolumn{2}{|c|}{ Source water } & \multicolumn{2}{|c|}{ Finished water } \\
\hline & & & $\begin{array}{c}\text { Concentra- } \\
\text { tion } \\
(\mu \mathrm{g} / \mathrm{L})\end{array}$ & $\begin{array}{c}\text { Benchmark } \\
\text { quotient }\end{array}$ & $\begin{array}{c}\text { Concentra- } \\
\text { tion } \\
(\mu \mathrm{g} / \mathrm{L})\end{array}$ & $\begin{array}{c}\text { Benchmark } \\
\text { quotient }\end{array}$ \\
\hline
\end{tabular}

\begin{tabular}{|c|c|c|c|c|c|}
\hline \multicolumn{6}{|c|}{ Other anthropogenic organic compounds-Continued } \\
\hline 3 & 6/18/04 10:15 AM & Methyl salicylate (U) & & $<$ & 0.5 \\
\hline 4 & 7/15/04 11:15 AM & Methyl salicylate (U) & $<0.5$ & $<$ & 0.5 \\
\hline 7 & 7/23/04 10:00 AM & Methyl salicylate (U) & $<0.5$ & $\mathrm{E}$ & 0.056 \\
\hline 8 & 7/14/04 10:00 AM & Methyl salicylate (U) & $<0.5$ & $<$ & 0.5 \\
\hline 10 & 6/17/04 10:45 AM & Methyl salicylate (U) & $<0.5$ & $<$ & 0.5 \\
\hline 11 & 6/22/04 10:30 AM & Methyl salicylate (U) & $<0.5$ & $<$ & 0.5 \\
\hline 12 & 6/22/04 1:30 PM & Methyl salicylate (U) & & & \\
\hline 14 & 6/29/04 10:40 AM & Methyl salicylate (U) & $<0.5$ & $<$ & 0.5 \\
\hline 5 & 7/30/04 11:40 AM & 4-Nonylphenol, diethoxy- (U) & $<5$ & $<$ & 5 \\
\hline 7 & 7/23/04 10:00 AM & 4-Nonylphenol, diethoxy- (U) & $<5$ & $<$ & 5 \\
\hline 8 & 7/14/04 10:00 AM & 4-Nonylphenol, diethoxy- (U) & $<5$ & $<$ & 5 \\
\hline 9 & 6/23/04 10:30 AM & 4-Nonylphenol, diethoxy- (U) & $<5$ & $<$ & 5 \\
\hline 10 & $6 / 17 / 04$ 10:45 AM & 4-Nonylphenol, diethoxy- (U) & $<5$ & $<$ & 5 \\
\hline 11 & $6 / 22 / 04$ 10:30 AM & 4-Nonylphenol, diethoxy- (U) & $<5$ & $<$ & 5 \\
\hline 12 & 6/22/04 1:30 PM & 4-Nonylphenol, diethoxy- (U) & & & \\
\hline 14 & 6/29/04 10:40 AM & 4-Nonylphenol, diethoxy- (U) & E 3.2 & $<$ & 5 \\
\hline 9 & 6/23/04 10:30 AM & Tri(2-chloroethyl)phosphate (TCEP) (U) & $<\quad 0.5$ & $<$ & 0.5 \\
\hline
\end{tabular}


Appendix 1. Concentration and benchmark quotient values for detected anthropogenic organic compounds in samples of source water and associated finished water, Connecticut SWOA study.-Continued

[E, estimated value; $\mu \mathrm{g} / \mathrm{L}$, micrograms per liter; <, less than; red type indicates blended water]

\begin{tabular}{lll} 
E & .083 & $\begin{array}{l}\text { Estimated value } \\
\text { Not analyzed }\end{array}$ \\
\hline$<$ & 0.5 & Blended source \\
& 0.0071 & Detected value above the reporting limit \\
0.1 & BQ value at or above 0.1 \\
\hline & BQ value at or above 1
\end{tabular}

\begin{tabular}{|c|c|c|c|c|c|c|c|c|}
\hline \multirow{2}{*}{$\begin{array}{c}\text { Well } \\
\text { number } \\
\text { (see } \\
\text { fig. 2) }\end{array}$} & \multirow[b]{2}{*}{$\begin{array}{l}\text { Sample date } \\
\text { and time }\end{array}$} & \multirow[b]{2}{*}{ Regulated (R) or unregulated (U) compound } & \multicolumn{3}{|c|}{ Source water } & \multicolumn{3}{|c|}{ Finished water } \\
\hline & & & & $\begin{array}{l}\text { oncentra- } \\
\text { tion } \\
\text { ( } \mu \mathrm{g} / \mathrm{L})\end{array}$ & $\begin{array}{c}\text { Benchmark } \\
\text { quotient }\end{array}$ & & $\begin{array}{l}\text { Oncentra- } \\
\text { tion } \\
\text { ( } \mu \mathrm{g} / \mathrm{L})\end{array}$ & $\begin{array}{c}\text { Benchmark } \\
\text { quotient }\end{array}$ \\
\hline \multicolumn{9}{|c|}{ Other anthropogenic organic compounds-Continued } \\
\hline 10 & 6/17/04 10:45 AM & Tri(2-chloroethyl)phosphate (TCEP) (U) & $<$ & 0.5 & & $<$ & 0.5 & \\
\hline 14 & 6/29/04 10:40 AM & Tri(2-chloroethyl)phosphate (TCEP) (U) & $\mathrm{E}$ & 0.13 & & $<$ & 0.5 & \\
\hline 3 & 6/18/04 10:15 AM & Tributyl phosphate (U) & & & & $<$ & 0.5 & \\
\hline 4 & 7/15/04 11:15 AM & Tributyl phosphate (U) & $<$ & 0.5 & & $<$ & 0.5 & \\
\hline 9 & 6/23/04 10:30 AM & Tributyl phosphate (U) & $<$ & 0.5 & & $<$ & 0.5 & \\
\hline 10 & 6/17/04 10:45 AM & Tributyl phosphate (U) & $<$ & 0.5 & & $<$ & 0.5 & \\
\hline 11 & 6/22/04 10:30 AM & Tributyl phosphate (U) & $<$ & 0.5 & & $<$ & 0.5 & \\
\hline 12 & 6/22/04 1:30 PM & Tributyl phosphate (U) & & & & & & \\
\hline 14 & 6/29/04 10:40 AM & Tributyl phosphate (U) & $\mathrm{E}$ & 0.16 & & $<$ & 0.5 & \\
\hline 3 & 6/18/04 10:15 AM & Triphenyl phosphate (U) & & & & $<$ & 0.5 & \\
\hline 4 & 7/15/04 11:15 AM & Triphenyl phosphate (U) & $<$ & 0.5 & & $<$ & 0.5 & \\
\hline 11 & 6/22/04 10:30 AM & Triphenyl phosphate (U) & $<$ & 0.5 & & $<$ & 0.5 & \\
\hline 12 & 6/22/04 1:30 PM & Triphenyl phosphate (U) & & & & & & \\
\hline 14 & 6/29/04 10:40 AM & Triphenyl phosphate (U) & $\mathrm{E}$ & 0.083 & & $<$ & 0.5 & \\
\hline
\end{tabular}

